\title{
A magyar közoktatásban zajló privatizáció és annak hatásai
}

A 2010-tól napjainkig tartó idôszakban a magyar közoktatás tulajdonosi szerkezetében két nagy horderejú változás történt: az önkormányzati iskolák „államosítása”, központi kormányzati tulajdonba vétele, valamint a közösségi tulajdonban lévó iskolák jelentốs részének a kormányzat által támogatott privatizációja, különbözó egyházi felekezeteknek való átadása. A tanulmány

áttekintést nyújt a tulajdonosi szerkezet átalakulásáról és a privatizációs folyamatot serkentố kormányzati eszközrendszerról.

Ezt követóen a szerzók elemzik a privatizációs folyamat hatékonyságra, minóségre, eredményességre, a közoktatási szelekció mértékére, valamint a roma tanulók szegregációjára gyakorolt hatását. A tanulmány a feltárt problémák. megoldásával kapcsolatos néhány oktatáspolitikai dilemma felvázolásával zárul.

\section{Bevezetés}

\begin{abstract}
A z iskolai kezdőszakaszban (ISCED1) a közoktatási intézmények tulajdonosi szerkezetét Európában alapvetően a közösségi tulajdon dominanciája jellemzi, a legtöbb országban az iskolák nagy többsége önkormányzati, vagy kisebb részben központi kormányzati tulajdonban van (1. ábra). Ennek ellenére minden európai országban müködnek magántulajdonban lévő iskolák. Ezek tulajdonosai non-profit szervezetek, egyházak, üzleti vállalkozások vagy magánszemélyek. Négy olyan európai ország van csupán, ahol hosszú ideje a magántulajdonban lévő iskolák meghatározó súlyú szereplői az iskola kezdőszakaszának: Hollandiában és Belgiumban az ezen a szinten tanuló gyerekek kétharmada, Spanyolországban a harmada, Dániában pedig a negyede magániskolában tanul. Mivel ezekben az országokban a magánoktatás nagy súlya sokkal inkább történeti fejlődés, semmint az elmúlt évtizedek oktatáspolitikai döntéseinek az eredménye, a továbbiakban nem foglalkozunk velünk. A magyar közoktatás tulajdonosi szerkezetének alakulása szempontjából sokkal fontosabbak azok az országok, amelyekben a közösségi tulajdon a domináns.
\end{abstract}


Ercse Kriszta - Radó Péter: A magyar közoktatásban zajló privatizáció és annak hatásai

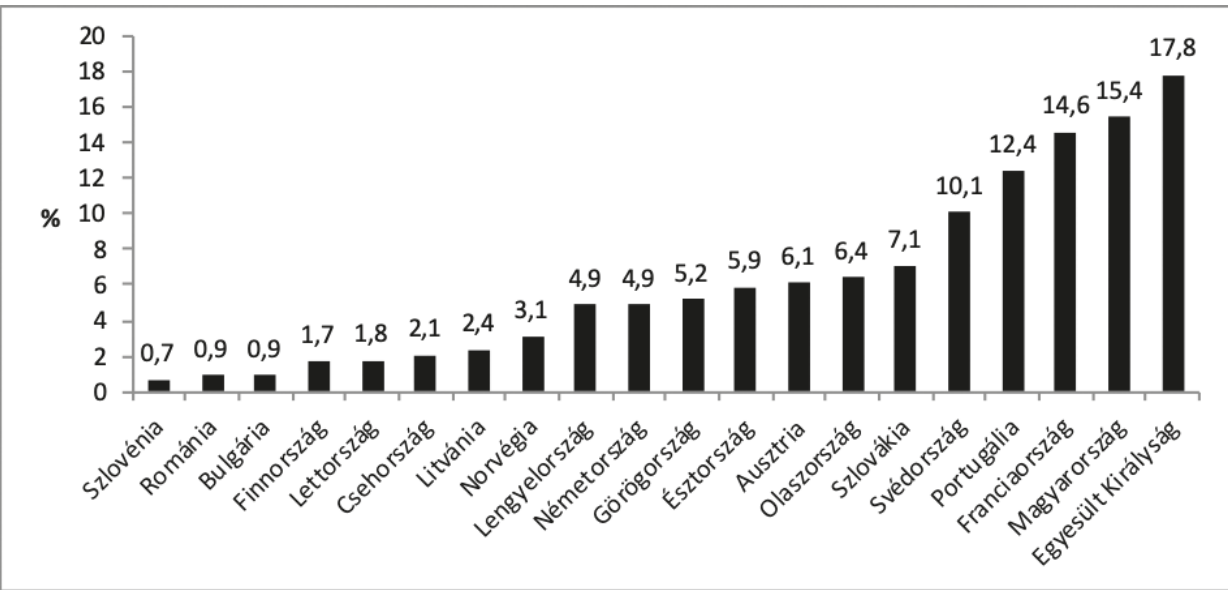

1. ábra. A magániskolákban tanuló általános iskolások aránya 2015-ben azokban az európai országokban, ahol az általános iskolai oktatásban a közösségi szektor túlsúlya a jellemzö (Forrás: Világbank, oktatásstatisztikai adatbázis ${ }^{1}$ )

Miközben tehát ezekben az országokban egyértelmü a közösségi szektor dominanciája, abban a tekintetben, hogy a magániskolai hálózat kiterjedtsége milyen mértékủ rendszerszintű hatást gyakorol, igen jelentős különbségek vannak. Szlovéniában, Romániában, Bulgáriában, Finnországban és néhány más európai országban például a magániskolák súlya igen csekély, lényegében csak speciális kínálatbővítő szerepük van. Ezekben az országokban az oktatási rendszer általános jellemzőire és teljesítményére a magániskolák müködése nem gyakorol érdemi hatást. Van azonban öt olyan európai ország, ahol a közösségi intézmények dominanciája ellenére a magániskolai hálózatban tanuló általános iskolások aránya 2015-ben meghaladta a 10 százalékot, ahol tehát a magánszektor súlyánál fogva képes hatást gyakorolni a közoktatási rendszer egészére. Ezek az országok Svédország (10,1\%), Portugália (12,4\%), Franciaország (14,6\%), Magyarország $(15,4 \%)$ és az Egyesült Királyság (17,8\%). Portugáliában már az ezredfordulón is magas volt a magániskolákba járó tanulók aránya $(9,6 \%)$, s azóta csak csekély mértékben nőtt, Franciaországban pedig ez az arány 2000-ben pont akkora volt, mint 2015-ben. Csupán három olyan európai ország van tehát, ahol az ezredforduló óta jelentős privatizáció zajlott le: Svédország, Magyarország és az Egyesült Királyság. Az általános iskolák privatizációja mindhárom országban igen jelentős mértékű volt: a magántulajdonban lévő általános iskolák száma Svédországban és Magyarországon megközelítőleg félezerre, az Egyesült Királyságban igen rövid idő alatt négyezer közelébe nőtt. A privatizációs folyamat Svédországban az ezredforduló után egyenletes tempóban zajlott, 2012-ben azonban megtorpant. Magyarországon szintén 2012-ig hasonló egyenletes növekedés zajlott, utána azonban a magániskolákban tanuló diákok arányának növekedése jelentősen felgyorsult. E tekintetben a fordulat éve az Egyesült Királyságban is 2012 volt: amíg az ezredfordulótól 2011-ig a magántulajdonban lévő általános iskolákban tanuló diákok aránya stabilan 5 százalék körül alakul, 2012-től négy év alatt az arányuk 5,1 százalékról 17,8 százalékra növekedett (2. ábra).

${ }^{1}$ https://databank.worldbank.org/data/source/education-statistics-\%5e-all-indicators 


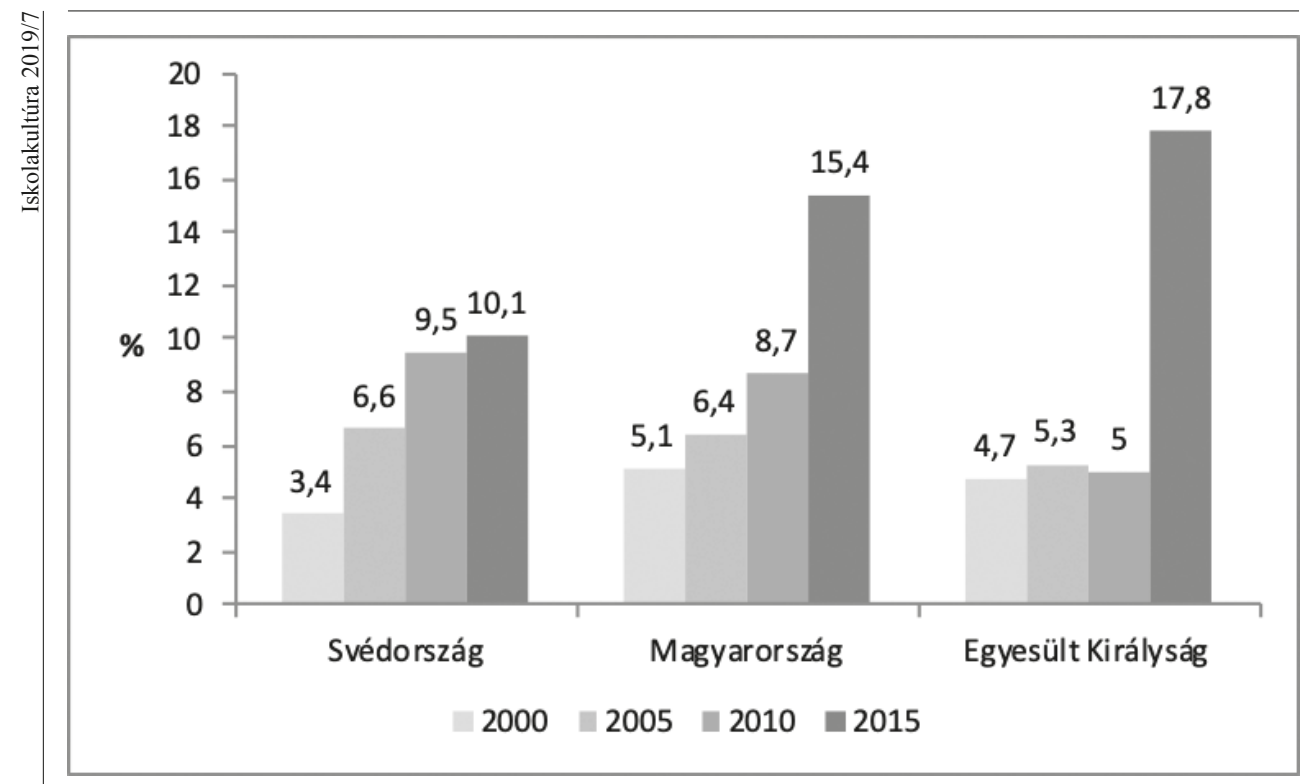

2. ábra. A magániskolákban tanuló általános iskolások arányának változása Svédországban, Magyarországon és az Egyesült Királyságban 2000-2015 között (Forrás: Világbank, oktatásstatisztikai adatbázis)

Mint ahogy az eddigiekből látszik, a magyar közoktatásban az elmúlt években lezajlott és jelenleg sem lezárt privatizációs folyamat európai összehasonlításban is jelentős mértékü átrendeződés. A magyar oktatáspolitikai közbeszédet érthető módon ma is az „,államosítással”, az oktatásirányítás szélsőségesen erős centralizációjával, az intézményi autonómiák felszámolásával, illetve mindezek már jól dokumentálható következményeivel kapcsolatos diskurzus uralja. Ugyanakkor a magyar közoktatásban zajló folyamatok megértéséhez szükség van az ezzel ellentétes irányú folyamatok megértésére és következményeik feltárására is. A továbbiakban arra teszünk kísérletet, hogy feltérképezzük az „államosítás” és a privatizáció mértékét, mechanizmusát és következményeit.

\section{A magyar közoktatás tulajdonosi szerkezetének átalakulása}

2010 óta a magyar közoktatás intézményrendszerének tulajdonosi szerkezete gyökeresen átalakult. Ez az átalakulás két párhuzamos, de ellentétes hatású, önmagukban is igen jelentős változás eredménye: (1) A központi kormányzati tulajdon expanziója: a 2011es Köznevelésröl szóló törvény alapján 2013-ban megtörtént az összes önkormányzati tulajdonban lévő iskola központi kormányzati tulajdonba vétele, melyet a nyilvános diskurzusban kissé pontatlanul ugyan, de igen kifejezően ,államosításnak” nevezünk. Ezzel párhuzamosan zajlott a nem egyházi magántulajdonban lévő középfokú szakképzési intézmények jelentős részének a kiszorítása, ami tovább növelte a kormányzati tulajdonban lévő iskolahálózat arányát. (2) Privatizáció: az egyházi tulajdonban lévő iskolahálózat növekedésének kormány által támogatott felgyorsulása és - jóval kisebb mértékben - a nem egyházi magániskolák számának növekedése 2014-től együttesen a közösségi tulajdonban lévő iskolák arányának csökkentését eredményezték. 


\section{Az önkormányzati iskolahálózat „államosítása”}

Szakmai értelemben a magyar iskolák 1985-ben váltak autonóm intézményekké. A rendszerváltást követően az 1993-as közoktatási törvény az iskolákkal kapcsolatos tulajdonosi jogokat az önkormányzatoknak adta át. Ez a lépés egy átfogó közigazgatási decentralizációs folyamat részét képezte, melynek keretében minden helyben nyújtott közszolgáltatás kötelező önkormányzati feladattá vált. Döntéshozatali kompetenciák tekintetében az önkormányzatok az általános és középfokú intézmények működtetésével kapcsolatos tulajdonosi felelősség teljes körét megkapták: jóváhagyták az iskola programját, megállapították az iskolák költségvetését, kiválasztották és kinevezték az iskolák igazgatóit és rendelkeztek az iskolák jogi, pénzügyi és szakmai elszámoltathatóságának biztosításával kapcsolatos elsődleges felelősséggel. Ezzel párhuzamosan megtörtént az iskolák gazdálkodási, intézményi és szakmai autonómiájának megerősítése. Az 1995ben elfogadott első Nemzeti Alaptanterv e decentralizált kormányzási mechanizmushoz illeszkedő kétszintü tartalmi szabályozási rendszert vezetett be. Az ezt követő másfél évtized kormányzatai fokozatosan kiépítették a decentralizációhoz illeszkedő kormányzás mechanizmusait: több körben megtörtént a normatív, fiskális decentralizáción alapuló finanszírozási rendszer finomhangolása, egy keresletvezérelt, az intézményi szükségletek sokféleségéhez alkalmazkodó szakmai szolgáltató és pedagógus továbbképzési rendszer kiépítése, a tankönyvpiac részleges minőségbiztosításának létrehozása, az intézményi minőségirányítás rendszerének a felépítése, valamint a tanulók teljesítményének rendszeres mérését szolgáló mechanizmus létrehozása. (Az egyetlen olyan fontos kormányzati alrendszer, amelynek létrehozása elmaradt, egy intelligens és professzionális külsö intézményértékelési rendszer létrehozása volt.)

A 2011-es Köznevelési Törvény alapján 2013-tól a központi kormányzat átvette az önkormányzatoktól az iskolák müködtetésével kapcsolatos összes tulajdonosi jog gyakorlását, valójában tehát tulajdonosváltás történt. Az iskolák által használt épületek önkormányzati tulajdonban maradtak, de a kormány ingyenes használatába kerültek, s e tulajdonosi joghoz - eltekintve egy rövid ideig fennálló, a visszatérő működési kiadások finanszírozására vonatkozó pénzügyi kötelezettségtől - nem kapcsolódott semmilyen tulajdonosi döntéshozatali jogosultság. (A visszatérő müködési kiadások finanszírozását 2015-ben vette át a központi költségvetés az önkormányzatoktól. Ettől kezdve az önkormányzatoknak semmilyen, a közoktatással kapcsolatos felelősségük nincs. )

Amint azt már jeleztük, az iskolák ,államosítása” nem csupán egyszerü tulajdonosváltást jelentett, hanem az oktatás kormányzási rendszerének mindenre kiterjedő átalakítását. Az iskolák mint önállóan regisztrált gazdálkodó szervezetek megszüntek, beleolvadtak az újonnan létrehozott, majd pedig számos alkalommal átszervezett Klebelsberg Intézményfenntartó Központba (KLIK). Az iskolák pedagógusai a KLIK alkalmazottaivá, az iskolák a KLIK telephelyeivé váltak. Lényegében minden fontosabb iskolavezetési, pénzügyi gazdálkodási, humánerőforrás-gazdálkodási és szakmai döntési jogosultság a KLIK tankerületi központjaihoz került, a központok tehát 2013 óta kívülről „mikromenedzselik” az iskolákat. Mindezzel együtt megtörtént a kormányzás teljes eszközrendszerének (finanszírozás, tartalmi szabályozás, minőségértékelés, szakmai szolgáltató rendszer, tankönyvkiadás, stb.) az új bürokratikus centralizáción alapuló oktatásirányítási rendszerhez igazítása. Mindösszesen, a közösségi tulajdonban lévő iskolahálózat teljes mértékben központi kormányzati tulajdonba került (1. táblázat). 
1. táblázat. A közoktatás tulajdonosi szerkezetének átalakulása (2010-2016, Forrás: Varga, 2018)

\begin{tabular}{lccc}
\hline \multicolumn{4}{c}{$\begin{array}{c}\text { Az egyes tulajdonosi körök részesedése a közoktatási intézményhálózaton belül } \\
(\%)\end{array}$} \\
\cline { 2 - 4 } & $\begin{array}{c}\text { Kormányzati } \\
\text { tulajdonban lévő iskolák } \\
\text { aránya }\end{array}$ & $\begin{array}{c}\text { Önkormányzatok } \\
\text { tulajdonában lévö } \\
\text { iskolák aránya }\end{array}$ & $\begin{array}{c}\text { Magántulajdonban lévö } \\
\text { iskolák aránya } \\
\text { (egyházi és egyéb } \\
\text { magániskolák együtt) }\end{array}$ \\
\hline Altalános iskolai oktatás & & 13,9 \\
\hline 2010 & 1,4 & 84,7 & 18,9 \\
\hline 2013 & 80,1 & 1,1 & 31,8 \\
\hline Középfokú oktatás & & 34,6 \\
\hline 2010 & 2,8 & 65,4 & \\
\hline 2013 & 64,6 & 0,8 & \\
\hline
\end{tabular}

\section{A magániskolák kiszoritása az iskolarendszerü szakképzésben}

Részben demográfiai okból, részben pedig a tizenhét és tizennyolc évesek körében csökkenő közoktatási részvétel miatt 2010 és 2016 között a középfokú oktatásban részt vevő tanulók létszáma 24 százalékkal csökkent. Ez a csökkenés azonban egyenlőtlenül oszlott el a három középfokú iskolatípus között. Miközben a gimnáziumokban tanuló diákok aránya ugyanebben az időszakban 34,4 százalékról 41,8 százalékra növekedett, a két középfokú szakképző intézményben tanulók aránya viszont csökkent: a szakgimnáziumokban (volt szakközépiskolákban) 41,6 százalékról 38,5 százalékra, a szakközépiskolákban (volt szakiskolákban) pedig 22,4 százalékról 18 százalékra. A 2011-es szakképzési törvény alapján a kormányzat a Megyei Fejlesztési és Képzési Bizottságokon keresztül évente intézményenként és szakmánként állapítja meg a közfinanszírozott szakképzési keretszámokat. A folyamatosan csökkenő tanulólétszámok körülményei között a Bizottságok egyértelmüen előnyben részesítették az állami és egyházi tulajdonban lévő szakképző intézményeket.

A nem egyházi magántulajdonban lévő intézmények túlélési esélyeit tovább csökkentette a szakgimnáziumok tanterveinek megváltoztatása 2016-tól. Ennek alapján számos szakképzési programban a szakmai vizsgákat a tanulók nem egy érettségi utáni poszt-szekundér program végén, hanem az érettségi vizsgával azonos időpontban kell letegyék, ami jelentős mértékben csökkentette az érettségi vizsgára való felkészítést szolgáló általános oktatási időkeretet. Ez lényegében megszüntette a poszt-szekundér oktatásban biztosított szakmai képzés iránti keresletet és csökkentette a szakgimnáziumi oktatás népszerüségét. Összességében, a nem egyházi tulajdonban lévő magániskolák aránya, illetve az általuk oktatott tanulók aránya jelentős mértékben csökkent, s a közeljövőben további csökkenésük várható (3. ábra). 
Ercse Kriszta - Radó Péter: A magyar közoktatásban zajló privatizáció és annak hatásai

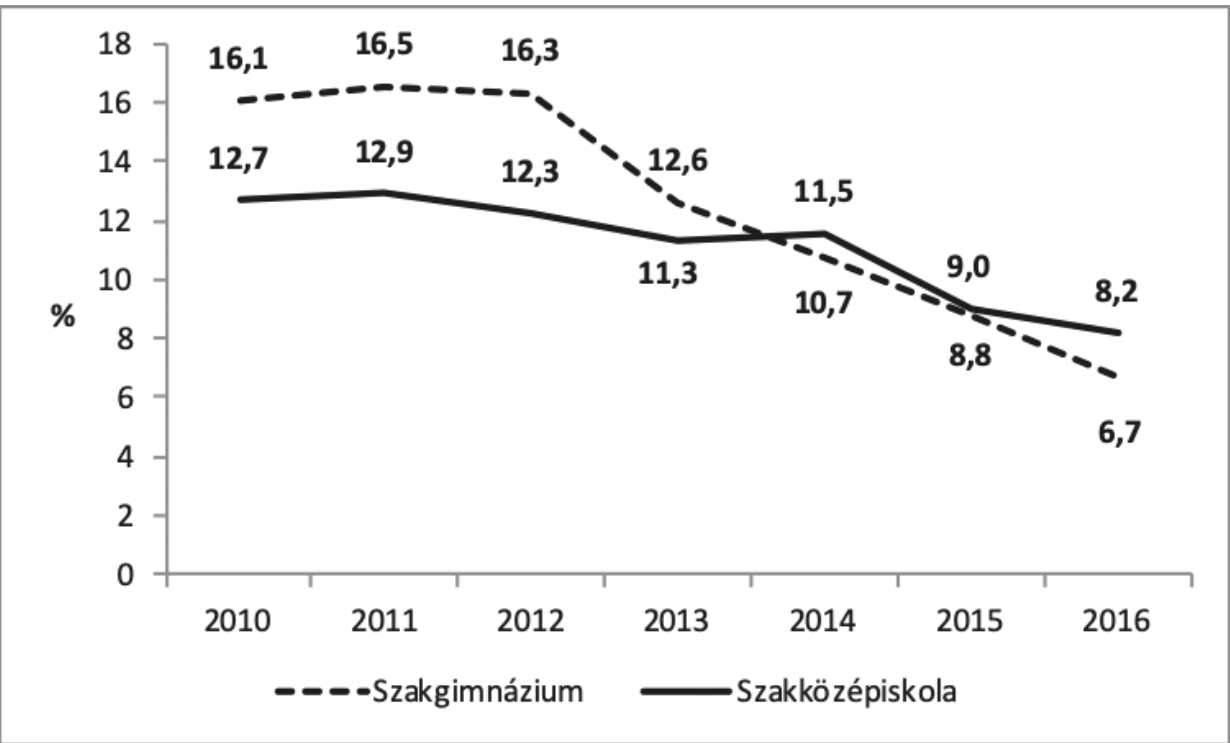

3. ábra. A nem egyházi magánintézményekbe járó tanulók aránya a középfokú szakképzésben (Forrás: Varga, 2018)

\section{Az egyházi magániskolák hálózatának expanziója}

Néhány kivételtől eltekintve az egyházi iskolahálózat gyors bővülése a nagyszámú már müködő önkormányzati, később állami tulajdonban lévő iskola különböző keresztény egyházaknak való átadásának az eredménye. Ez a folyamat a 2011-es köznevelési törvény elfogadása után gyorsult fel, majd pedig 2013-tól, a közösségi iskolák KLIK-be olvasztása után lelassult. Mint az a 2. táblázat adataiból jól látszik, az egyházak igen rövid idő alatt az általános iskolai és középfokú oktatás jelentős súlyú szereplőivé léptek elöre.

2. táblázat. Az egyházak tulajdonban lévö magániskola hálózat részesedése az általános iskolai és a középfokú intézményhálózaton belül (Forrás: Varga, 2018)

\begin{tabular}{ccccc}
\hline \multirow{2}{*}{ Év } & \multicolumn{2}{c}{ Általános iskolai oktatás } & \multicolumn{2}{c}{ Középfokú oktatás } \\
\cline { 2 - 5 } & Iskolák (\%) & Tanulók (\%) & Iskolák (\%) & Tanulók (\%) \\
\hline 2010 & 9,4 & 7,4 & 10,4 & 6,7 \\
\hline 2016 & 15,8 & 17,4 & 22,8 & 15,1 \\
\hline
\end{tabular}

\section{A nem egyházi magánoktatás bővülése az általános iskolai oktatásban}

A vizsgált időszakban az egyházi iskolahálózat dinamikus bővülésével párhuzamosan 2014-ig a nem egyházi magánoktatás kismértékü zsugorodása volt megfigyelhető. Ettől kezdve azonban az általános iskolai és a középfokú magánoktatásban eltérő irányú változások zajlottak, illetve zajlanak napjainkban is (3. táblázat). Középfokon az állami oktatási hálózaton belül változatlanul jelentős „elitgimnáziumi” kínálat elszívó hatása, a demográfiai okokkal magyarázható tanulószám-csökkenés, valamint a nem egyházi 
magániskolák szakképzésből való kiszorulása összegződő hatásaként a magániskolákban tanuló diákok aránya az időszak végéig csökkent. Ezzel szemben - mint arról a továbbiakban bővebben lesz szó - az állami általános iskolák szülők által érzékelt gyorsan romló minősége miatt alapfokon újra növekedni kezdett a nem egyházi magánintézmények népszerüsége. Az állami oktatással szembeni alternatívák keresése különösen a nagyobb fizetőképes kereslettel rendelkező középosztályi szülők körében erősödött fel. A nem egyházi magániskolák kis mérete miatt az intézményeik aránya gyorsabban növekszik, mint az általuk oktatott tanulók aránya.

3. táblázat. A nem egyházi tulajdonban lévő magániskola-hálózat részesedése az általános iskolai és a középfokú intézményhálózaton belül (Forrás: Varga, 2018)

\begin{tabular}{ccccc}
\hline \multirow{2}{*}{$\mathbf{E} \mathbf{v}$} & \multicolumn{2}{c}{ Általános iskolai oktatás } & \multicolumn{2}{c}{ Középfokú oktatás } \\
\cline { 2 - 5 } & Iskolák (\%) & Tanulók (\%) & Iskolák (\%) & Tanulók (\%) \\
\hline 2010 & 4,5 & 1,8 & 21,4 & 12,3 \\
\hline 2011 & 4,4 & 1,8 & 22,2 & 12,5 \\
\hline 2012 & 4,2 & 1,8 & 20,4 & 12,2 \\
\hline 2013 & 3,9 & 1,7 & 18,8 & 10,2 \\
\hline 2014 & 4,0 & 1,8 & 17,6 & 9,5 \\
\hline 2015 & 4,2 & 2,0 & 20,9 & 8,2 \\
\hline 2016 & 4,8 & 2,3 & 20,6 & 7,4 \\
\hline
\end{tabular}

Összegződő hatások: a közoktatás tulajdonosi szerkezetének átrendezödése

Az eddig ismertetett folyamatok összegződő hatásaként a közoktatási iskolahálózat tulajdonosi szerkezete 2010 óta jelentős mértékben átalakult. E változás két kulcseleme a közösségi tulajdonban lévő iskolahálózat arányának folyamatos csökkenése és a magániskolai hálózat belső szerkezetének átalakulása.

A közösségi tulajdonban lévő általános iskolai és középfokú oktatás visszaszorulása kimutatható az önkormányzati/állami iskolák számának, valamint - ami még fontosabb - az általuk oktatott tanulók arányának csökkenésében is. A csökkenés különösen szembetünő az általános iskolai oktatásban, ahol a közösségi tulajdon az évtized elején még domináns volt. Ennek legfontosabb oka az, hogy az egyházak tulajdonába került közösségi általános iskolák nagy többsége korábban önkormányzati iskola volt. Középfokon az intézmények alig több mint fele maradt állami tulajdonban. Ez azonban az állami intézmények lényegesen nagyobb mérete miatt nem járt ugyanilyen mértékü tanulóarány-csökkenéssel, a diákok több mint háromnegyede még állami intézményben tanul (4. táblázat). 
Ercse Kriszta - Radó Péter: A magyar közoktatásban zajló privatizáció és annak hatásai

4. táblázat. A közösségi tulajdonban lévő oktatási intézmények és az általuk oktatott tanulók arányának csökkenésen (Forrás: Varga, 2018)

\begin{tabular}{ccccc}
\hline \multirow{2}{*}{ Év } & \multicolumn{2}{c}{ Általános iskolai oktatás } & \multicolumn{2}{c}{ Középfokú oktatás } \\
\cline { 2 - 5 } & Iskolák (\%) & Tanulók (\%) & Iskolák (\%) & Tanulók (\%) \\
\hline 2010 & 86,1 & 90,8 & 68,2 & 81,1 \\
\hline 2011 & 84,4 & 89,1 & 66,1 & 79,6 \\
\hline 2012 & 81,6 & 86,1 & 64,6 & 76,4 \\
\hline 2013 & 81,1 & 84,9 & 65,4 & 76,8 \\
\hline 2014 & 80,8 & 84,5 & 65,9 & 76,7 \\
\hline 2015 & 80,4 & 83,9 & 57,4 & 77,2 \\
\hline 2016 & 79,4 & 83,0 & 56,6 & 77,5 \\
\hline
\end{tabular}

Ami az általános iskolai magánszektor belső összetételét illeti, az ezredforduló óta az egyházi iskolahálózat az intézmények számát és az általuk oktatott tanulók arányát tekintve is dominánssá vált. Miközben a nem egyházi magánintézmények aránya az egész időszakban lényegében stagnált (igen csekély mértékben növekedett), az egyházi iskolák és az általuk oktatott diákok aránya a háromszorosára növekedett (5. táblázat).

5. táblázat. Az egyházi és egyéb magániskolák, valamint az általuk oktatott tanulók arányának változása az általános iskolai oktatásban (Forrás: Varga, 2018)

\begin{tabular}{ccccc}
\hline \multirow{2}{*}{ Év } & \multicolumn{2}{c}{ Egyházi iskolák } & \multicolumn{2}{c}{ Egyéb magániskolák } \\
\cline { 2 - 5 } & Iskolák (\%) & Tanulók (\%) & Iskolák (\%) & Tanulók (\%) \\
\hline 2001 & 5,0 & 4,5 & 2,6 & 1,1 \\
\hline 2002 & 5,2 & 4,7 & 2,6 & 1,1 \\
\hline 2003 & 5,5 & 5,0 & 2,7 & 1,2 \\
\hline 2004 & 5,9 & 5,3 & 3,0 & 1,4 \\
\hline 2005 & 6,3 & 5,5 & 3,1 & 1,3 \\
\hline 2006 & 6,4 & 5,7 & 3,2 & 1,4 \\
\hline 2007 & 8,0 & 6,2 & 4,0 & 1,7 \\
\hline 2008 & 8,5 & 6,6 & 4,4 & 1,7 \\
\hline 2009 & 9,1 & 7,0 & 4,5 & 1,7 \\
\hline 2010 & 9,4 & 7,4 & 4,5 & 1,8 \\
\hline 2011 & 11,2 & 9,1 & 4,4 & 1,8 \\
\hline 2012 & 14,1 & 12,2 & 4,3 & 1,7 \\
\hline 2013 & 15,0 & 13,3 & 3,9 & 1,8 \\
\hline 2014 & 15,2 & 13,8 & 4,0 & 2,0 \\
\hline 2015 & 15,5 & 14,1 & 4,2 & 2,3 \\
\hline 2016 & 15,8 & 14,7 & 4,8 & \\
\hline
\end{tabular}


Hasonló folyamat ment végbe a középfokú oktatásban is. Az évezred elején még közel kétszer annyi nem egyházi magániskola müködött Magyarországon, mint egyházi. Az azóta eltelt időszakban a nem egyházi magániskolák aránya egy ideig növekedett, majd 2014-től csökkenni kezdett; jelenleg a súlyuk a középfokú oktatásban nagyjából akkora, mint az ezredfordulón volt. Ezzel szemben a középfokú oktatásban az egyházi iskolahálózat mind az iskolák, mint pedig a tanulók arányát tekintve közel háromszorosára nőtt, jelenleg már nagyon iskolahálózattal rendelkeznek, mint a nem egyházi magániskolák (6. táblázat).

6. táblázat. Az egyházi és egyéb magániskolák, valamint az általuk oktatott tanulók arányának változása a középfokú oktatásban (Forrás: Varga, 2018)

\begin{tabular}{ccccc}
\hline \multirow{2}{*}{ Év } & \multicolumn{2}{c}{ Egyházi iskolák } & \multicolumn{2}{c}{ Egyéb magániskolák } \\
\cline { 2 - 5 } & Iskolák (\%) & Tanulók (\%) & Iskolák (\%) & Tanulók (\%) \\
\hline 2001 & 8,2 & 5,3 & 14,9 & 7,8 \\
\hline 2002 & 8,2 & 5,5 & 15,5 & 7,8 \\
\hline 2003 & 8,3 & 5,7 & 16,6 & 8,5 \\
\hline 2004 & 8,3 & 5,8 & 17,2 & 8,8 \\
\hline 2005 & 8,6 & 6,0 & 18,0 & 8,8 \\
\hline 2006 & 8,7 & 6,2 & 18,4 & 8,6 \\
\hline 2007 & 9,3 & 6,2 & 20,2 & 9,6 \\
\hline 2008 & 9,8 & 6,5 & 20,9 & 10,2 \\
\hline 2009 & 10,3 & 6,6 & 21,4 & 11,5 \\
\hline 2010 & 10,4 & 6,7 & 21,4 & 12,3 \\
\hline 2011 & 11,8 & 7,9 & 22,2 & 12,5 \\
\hline 2012 & 15,0 & 11,4 & 20,4 & 12,2 \\
\hline 2013 & 15,8 & 13,0 & 18,8 & 10,2 \\
\hline 2014 & 16,6 & 13,9 & 17,5 & 9,5 \\
\hline 2015 & 21,8 & 14,6 & 20,9 & 8,2 \\
\hline 2016 & 22,8 & 15,1 & 20,6 & \\
\hline
\end{tabular}

Összességében a nem egyházi magániskolai hálózat lényegében megmaradt a speciális szülői-tanulói igények kielégítését szolgáló, a kínálatot gazdagító szerepben, az egyházi iskolahálózat azonban a fösodrú közoktatási szolgáltatások egyik legfontosabb szereplöjévé vált.

A közösségi és magántulajdonban lévő iskolahálózatok belső arányainak jelentős változása a tanulói és intézményi szint mellett kimutatható a települések szintjén is. Az Országos Kompetenciamérések adatai szerint csökkent azoknak a településeknek a száma és aránya, melyekben müködik önkormányzati, illetve állami vagy nem egyházi magániskola, míg az egyházi iskolával rendelkező települések száma és aránya a duplájára nőtt (7. táblázat). 
Ercse Kriszta - Radó Péter: A magyar közoktatásban zajló privatizáció és annak hatásai

7. táblázat. A közösségi, egyházi és nem egyházi magántulajdonban lévő iskolákkal rendelkezö települések számának és arányának változása (általános és szerkezetváltó középfokú iskolák, 2010-2016.

Forrás: OKM, 8. évfolyam)

\begin{tabular}{lcccc}
\hline & \multicolumn{2}{c}{$\begin{array}{c}\mathbf{2 0 1 0} \\
\mathbf{( 1 5 5 9} \text { település) }\end{array}$} & \multicolumn{2}{c}{$\begin{array}{c}\mathbf{2 0 1 6} \\
\text { (1524 település) }\end{array}$} \\
\cline { 2 - 5 } & $\begin{array}{c}\text { Települések } \\
\text { száma }\end{array}$ & $\begin{array}{c}\text { Települések } \\
\text { aránya (\%) }\end{array}$ & $\begin{array}{c}\text { Települések } \\
\text { száma }\end{array}$ & $\begin{array}{c}\text { Települések } \\
\text { aránya (\%) }\end{array}$ \\
\hline $\begin{array}{l}\text { Van önkormányzati/állami } \\
\text { iskola }\end{array}$ & 1506 & 96,6 & 1378 & 90,4 \\
\hline Van egyházi magániskola & 133 & 8,5 & 268 & 17,6 \\
\hline Van nem egyházi magániskola & 61 & 3,9 & 46 & 3,0 \\
\hline
\end{tabular}

Az egyházi iskolahálózat növekedésének van egy jelentős, hozzáféréssel kapcsolatos mellékhatása: közel négyszeresére nőtt azoknak a településeknek a száma, ahol kizárólag egyházi iskola múködik (8. táblázat). Mivel az egyházi iskolákban az adott felekezet hitvallása szerinti kötelező hittanoktatás folyik, ezeken a településeken sérül a szülök és a tanulók joga a saját vallásuknak megfelelő oktatásra, ami magában foglalja a hittan tanulását nem tartalmazó oktatáshoz való jogot is. Ezt a jogot kizárólag az ideológiailag semleges közösségi iskolák biztosíthatják, melyekben a hittanoktatás fakultatív extrakurrikuláris tanulási program. Azon a 137 településen tehát, ahol csupán egyházi iskola müködik, sérülnek a szülők nemzetközi egyezményekben rögzített emberi jogai. ${ }^{2}$

8. táblázat. Azon települések számának változása, ahol kizárólag egyházi tulajdonban lévö iskola müködik (2010-2015, Forrás: Tomasz 2017)

\begin{tabular}{lcccccc}
\hline & $\mathbf{2 0 1 0}$ & $\mathbf{2 0 1 1}$ & $\mathbf{2 0 1 2}$ & $\mathbf{2 0 1 3}$ & $\mathbf{2 0 1 4}$ & $\mathbf{2 0 1 5}$ \\
\hline Katolikus & 15 & 27 & 61 & 71 & 72 & 74 \\
\hline Református & 14 & 16 & 30 & 33 & 35 & 36 \\
\hline Baptista & 1 & 2 & 17 & 17 & 17 & 13 \\
\hline Keresztény kisegyház & 4 & 6 & 8 & 9 & 10 & 10 \\
\hline Görök katolikus & 1 & 4 & 4 & 4 & 4 & 4 \\
\hline Evangélikus & 1 & 1 & 2 & 2 & 2 & 2 \\
\hline Más egyház & 2 & 2 & 2 & 1 & 1 & 0 \\
\hline Összesen & 38 & 58 & 124 & $136^{*}$ & $139^{* *}$ & $137^{* * *}$ \\
\hline
\end{tabular}

* Az egyik településen két egyházi iskola

** Két településen két egyházi iskola

${ }^{2}$ Az Európai Unió Alapjogi Chartája 14. cikk, (3) bekezdés: [Az oktatáshoz való jog magában foglalja] ,a szülőknek azon jogát, hogy gyermekeik számára vallási, világnézeti vagy pedagógiai meggyőződésüknek megfelelő nevelést biztosítsanak." 


\section{A tulajdonosi szerkezet változását generáló oktatáspolitikai beavatkozások}

A közoktatás tulajdonosi szerkezetének megváltozása 2010 után nem spontán, az egyházi oktatással szembeni igények növekedésével magyarázható folyamatok, hanem tudatos és célzott kormányzati beavatkozások eredménye volt. Ebben az időszakban az Orbán-kormányok iskolahálózat-politikája három fajta eszközrendszer kombinációján alapult. Ezek a következők voltak: (1) az egyházi tulajdonban lévő iskolák számára megállapított speciális, a közösségi kontrollt gyengítő szabályok rögzítése, (2) az egész iskolarendszer kormányzását jellemző szélsőséges centralizáció szabályrendszerének fellazítása az egyházi iskolák számára, különösen az iskolai autonómia mértékével, a tantervi szabályozással és a tankönyvi kínálattal kapcsolatban, valamint (3) az egyházi intézményeket előnyben részesítő finanszírozás, és különböző negatív és pozitív ösztönzők alkalmazása. Az egyházi iskolahálózat bővülését segítő finanszírozási ösztönzők egy része a finanszírozási mechanizmusba kódolt elönyökkel, egy másik része pedig az ezen keresztül biztosított több költségvetési forrással operál.

\section{Preferenciális szabályozás és könnyitések}

Az egyházi iskolahálózat bővülését elősegítő kormányzati politika 2010 óta - mint ebben az időszakban minden más oktatáspolitikai beavatkozás-sorozat - nem valamilyen kidolgozott stratégián alapszik. Sokkal inkább az egyházakat előnyben részesítő egyedi preferenciális szabályok rögzítéséről és eseti döntésekröl van szó, melyek illeszkednek az oktatáspolitika általános irányvonalába. Más szavakkal: szinte minden, a kormányzat által kezdeményezett és megvalósított változtatás tartalmaz olyan elemeket, melyek preferenciális szabályokat vagy könnyítéseket tartalmaznak az egyházak számára. Ezek a könnyítések összességükben közvetlenül, vagy éppen nem szándékos mellékhatásként ösztönözték a közösségi tulajdonban lévő
A közoktatás tulajdonosi szerkezetének megváltozása 2010 után nem spontán, az egyházi oktatással szembeni igények növekedésével magyarázható folyamatok, hanem tudatos és célzott kormányzati beavatkozások eredménye volt. Ebben az idöszakban az Orbán-kormányok iskolahálózat-politikája három fajta eszközrendszer kombinációján alapult. Ezek a következók voltak: (1) az egyházi tulajdonban lévó iskolák számára megállapitott speciális, a közösségi kontrollt gyengitó szabályok rögzitése,

(2) az egész iskolarendszer kormányzását jellemzó szélsóséges centralizáció szabályrendszerének fellazitása az egyházi iskolák számára, különösen az iskolai autonómia mértékével, a tantervi szabályozással és a tankönyvi kinálattal kapcsolatban, valamint (3) az egyházi intézményeket elónyben részesitó finanszirozás, és különbözó negativ és pozitív ösztönzók alkalmazása. Az egyházi iskolahálózat bóvülését segitô finanszirozási ösztönzók egy része a finanszírozási mechanizmusba kódolt elónyökkel, egy másik része pedig az ezen keresztül biztosított több költségvetési forrással operál. 
iskolák egyházak számára történő átadásukkal megvalósuló privatizációját és az egyházi iskolahálózat növekedését.

Az önkormányzati iskolák egyházak számára való átadásának megkönnyítése a 2010-ben hivatalba lévő kormány egyik nyilvánvaló prioritása volt. Ezt jelezte egy szinte azonnali törvénymódosítás ${ }^{3}$, amely eltörölte azt a szabályt, hogy az egyháznak átadott iskola kiegészítő egyházi támogatását (amely a közösségi intézmények finanszírozásában a költségvetési támogatáson felül az önkormányzatok átlagos kiegészítését volt hivatva pótolni) öt évig az átadó önkormányzatoknak kellett fizetniük. A törvénymódosítást követően a kiegészítő támogatást már az átvétel első évétől az állami költségvetés biztosította, ami megszüntette az önkormányzatok átadással kapcsolatos ellenérdekeltségét (Tomasz, 2017).

Az egyházi tulajdonban lévő iskolahálózat bővülése szempontjából hatásukat tekintve a legfontosabb preferenciális szabályok és könnyítések az egyházi iskolák beiskolázási politikáinak szabályozásával kapcsolatosak. Általában a tanulók beiskolázásakor az iskolák kötelesek előnyben részesíteni az iskolaÁltalában a tanulók beiskolázásakor az iskolák kötelesek elónyben részesiteni az iskolakörzeten belül lakó gyerekeket. Ez a szabályozás nem korlátozza a szülók iskolaválasztási szabadságát, viszont korlátot szab annak, hogy az iskolák szelektív beiskolázási gyakorlatot követve féróhelyeiket iskolakörzeten kivülrôl jelentkezó gyerekekkel tölthessék fel. (Erre csak az iskolakörzeten belüli gyerekek felvétele után még fennmaradó üres féróhelyek erejéig van módjuk.) Ez a szabályozás azonban nem vonatkozik a magániskolákra, ezen belül az egyházi magániskolákra. körzeten belül lakó gyerekeket. Ez a szabályozás nem korlátozza a szülők iskolaválasztási szabadságát, viszont korlátot szab annak, hogy az iskolák szelektív beiskolázási gyakorlatot követve férőhelyeiket iskolakörzeten kívülröl jelentkező gyerekekkel tölthessék fel. (Erre csak az iskolakörzeten belüli gyerekek felvétele után még fennmaradó üres férőhelyek erejéig van módjuk.) Ez a szabályozás azonban nem vonatkozik a magániskolákra, ezen belül az egyházi magániskolákra. Az egyházi iskolákra vonatkozó speciális szabályozás szerint amennyiben egy egyházak tulajdonában lévő iskola egyoldalú nyilatkozattal kinyilvánítja, hogy közremüködik közoktatási szolgáltatás nyújtásában, jogosulttá válik állami költségvetési támogatásra. Ebben az esetben elméletileg az egyházi iskoláknak tanulólétszámuk minimum 25 százaléka erejéig iskolakörzeten belül élő gyerekeket kell felvenniük. Az egyházi iskolák iskolakörzeteinek meghatározása viszont rendkívül tágan történik: lényegében azonos azzal a településsel, ahol müködnek. (Egy közepes méretü város esetében például az iskolakörzet az egész település.) Ismereteink szerint e rendkívül megengedő szabályozás betartását sem ellenőrzi egyetlen hatóság sem. Ráadásul az egyházi iskolák nem kötelezettek hátrányos helyzetủ tanulók felvételére, és vallási alapon jogosultak felvételi szürést alkalmazni, így ez a szabályozás nem alkalmas arra, hogy mérsékelje az egyházi iskolák szelekciós gyakorlatát (Ercse, 2018.). ${ }^{4}$

3 A közoktatási törvény módosításáról szóló 2010. évi LI. törvény.

4 2011. évi CXC. törvény (NKt), 23. Az egyházi köznevelési intézmény és a magán köznevelési intézmény müködésére, valamint az állami nevelési-oktatási intézményekben megszervezhető hit- és erkölcsoktatásra vonatkozó sajátos szabályok, 33§-35/B. § 
Számos egyéb, az egyházi iskolák számára megállapított könnyítő szabályozás mellett egy további, számukra elönyt biztosító kivétel, hogy a magániskolákra nem terjed ki az a tanügyigazgatási rendszer, amely teljes mértékben felszámolta az állami iskolák korábban élvezett gazdálkodási, szervezeti és szakmai önállóságát. Az iskolákat müködtető egyházak lényegében ugyanazokat a tulajdonosi döntési jogokat gyakorolják, melyeket a 2011-es törvény előtti időszakban az önkormányzati iskolafenntartók: az igazgató kiválasztását és kinevezését, az iskolák programjának elfogadását, az éves költségvetés megállapítását stb. (Bizonyos egyházi fenntartók a korábbihoz képest kissé erőteljesebb kontrollt gyakorolnak az iskolák müködése felett, ez azonban általában nem éri el azt a mértéket, amikor már az iskolai autonómia jelentős korlátozásáról kellene beszélnünk.) Más szavakkal: az egyházi iskolákat tipikusan saját igazgatóik irányítják, és számos fontos döntés meghozatala a tantestület bevonásával történik. Az egyházi iskolák nagyobb autonómiája nagyobb mozgástérrel párosul abban a tekintetben, hogy mennyire kell alávetniük magukat azoknak a szélsőségesen centralizált rendszereknek, melyeket a kormányzat az állami iskolák vonatkozásában (elméletileg az egész közoktatási intézményrendszerre egységesen) alakított ki. Így például az egyházi iskolák saját kerettantervek alapján és külön, számukra kiadott tankönyvek segítségével oktatnak. Összességében az egyházi iskolák jelentős mértékben mentesülnek a szélsőséges centralizáción alapuló államosítás következményei alól, tehát - elméletileg - nagyobb mozgásterük van az egyszer már elért oktatási minőség megőrzése terén.

\section{Finanszírozási ösztönzök: párhuzamos rendszerek}

Mivel az „államosított” közösségi tulajdonban lévő iskolák önálló gazdálkodása az állami iskolafenntartói szervezetekbe való beolvadásuk miatt teljesen megszűnt, 2012 szeptemberétől eltérő finanszírozási mechanizmus jött létre az állami és magániskolák számára. Az állami iskolák minden kiadását közvetlenül az iskolafenntartó központ fizeti. A KLIK, majd 2016-tól a tankerületi központok költségvetésének megállapítása úgynevezett „,történeti alapon”, az előző évi költségvetést bázisnak tekintve történik. E mögött gyakorlatilag semmilyen komolyan vehető pénzügyi tervezés nem zajlik. Egyszerűen szólva: a központ eseti döntések alapján teljesíti a kifizetési kötelezettségeket addig, amíg a rendelkezésre álló pénzkeretek ezt lehetővé teszik. A kifizetési kötelezettségek teljesítése a pénzkeretek hozzávetőleges ismerete alapján eseti döntésekkel történik, amiben komoly szerepet játszik az intézményvezetők informális érdekérvényesítő képessége is. A visszatérő személyi kiadások tervezése elméletileg a szükséges és elismert tanítási órák számán alapszik, a gyakorlatban azonban semmilyen standardizáció nem érvényesül. A személyi kiadások kifizetésének alapja a mindenkori bértábla és a pedagógus és nem pedagógus alkalmazottak száma. A személyi kiadásokra rendelkezésre álló keretek és a fizetési kötelezettségek egyensúlyának fenntartása az alkalmazási döntések eseti direkt kontrolljával történik, melyek segítségével az alkalmazottak számát a központ alacsonyan tartja. Ez csak oly módon lehetséges, hogy a központok a legtöbb iskolában nem engedik feltölteni az elméletileg engedélyezett létszámkereteket.

A magániskolák személyi kiadásait is közvetlenül a kincstár folyósítja, a kiadások kalkulációja ugyanazon kritériumok alapján történik, mint ahogy elméletileg az állami iskolákban kellene történjen. A legnagyobb különbség az, hogy a magániskolákban az állam nem gyakorol semmilyen közvetlen befolyást az egyedi alkalmazási döntésekre, ezért azok fel tudják tölteni a számukra megfinanszírozott létszámkereteket. (Amennyiben rendelkeznek egyéb forrással is, azt túl is léphetik.) A müködési költségek finanszírozása esetében azonban gyökeresen eltérő a helyzet. Az egyházak és kisebbségi önkormányzatok által múködtetett iskolák tulajdonosai a 2012 előtti rendszernek megfelelően 
általános „fejkvóta” alapú normatív költségvetési támogatást kapnak. A nem egyházi (és nem kisebbségi önkormányzati) magániskolák azonban nem kapnak semmilyen visszatérő müködési kiadásaik fedezetét szolgáló költségvetési támogatást, azt saját forrásaikból kell fedezniük. Az egyházak finanszírozási helyzetét az évente több alkalommal megítélt nagy összegü eseti oktatási célú támogatások is javítják, melyekkel az egyházak lényegében szabadon gazdálkodhatnak.

A szakképző iskolák NGM általi átvétele és a szakképzési centrumok létrehozása óta az iskolarendszerü szakképzés finanszírozása elméletileg szektorsemleges mechanizmus: a személyi és müködési kiadások fedezetét az állami költségvetés biztosítja a szakképzési centrumok számára, amely - a tankerületi központokhoz hasonló módon - közvetlenül finanszírozza az intézményekben megjelenő költségek kifizetését. Mivel azonban a finanszírozás az évente intézményenként megállapított képzési létszámokon alapszik, amely szisztematikusan elönyben részesíti az állami intézményeket, az egyes tulajdonosi körök finanszírozása között mégis jelentős különbségek alakultak ki.

Összességében a magyar közoktatásban hat párhuzamos, eltérő mértékben centralizált finanszírozási mechanizmus müködik, melyek eltérő allokációs mechanizmust alkalmaznak és eltérő tervezési kritériumokon alapulnak (9. táblázat). E rendszer egyik véglete a továbbra is önkormányzatok által ellátott óvodai nevelés finanszírozása, mely változatlanul normatív és decentralizált. A másik véglet az állami általános iskolai és gimnáziumi oktatás, melynek finanszírozása teljes mértékben centralizált inputfinanszírozás (2016 óta részben dekoncentrált), és normativitást nyomokban sem tartalmaz. A kettő között a különböző finanszírozási mechanizmusok a bérkiadások direkt központi költségvetési finanszírozását kombinálják a dologi müködési költségek normatív finanszírozásával. (A nem-egyházi magániskolák kivételével, melyek nem kapnak müködési támogatást.) A finanszírozás egyetlen egységes eleme a bizonyos célhoz kötött kiegészítő támogatások (ingyenes tankönyv és gyermekélelmezés) tanulólétszám alapú normatív támogatása, melyet tulajdonosra való tekintet nélkül minden iskola megkap. Mindösszesen, a közoktatás finanszírozási rendszere alapjául szolgáló alapelvek nem világosak és a rendszer szinte teljesen átláthatatlan. Ebben a rendszerben összes visszatérő költségeiket bizosító állami támogatáson alapuló stabil gazdálkodásra csupán az önkormányzatok által fenntartott óvodáknak és az egyházak által fenntartott iskoláknak van módja. 


\begin{tabular}{|c|c|c|}
\hline \multicolumn{3}{|c|}{ 9. táblázat. Párhuzamos finanszírozás rendszerek a közoktatásban } \\
\hline $\begin{array}{l}\text { Intézménytípus/ } \\
\text { tulajdonos }\end{array}$ & $\begin{array}{l}\text { Finanszírozási } \\
\text { mechanizmus }\end{array}$ & Cél/finanszírozás alapja \\
\hline $\begin{array}{l}\text { Óvodák/önkormányzat } \\
\text { vagy magán }\end{array}$ & $\begin{array}{l}\text { Decentralizált normatív } \\
\text { finanszírozás }\end{array}$ & $\begin{array}{l}\text { - Iskola előtti nevelés minden } \\
\text { költsége/tanulólétszám } \\
\text { („fejkvóta”) }\end{array}$ \\
\hline $\begin{array}{l}\text { Általános iskolai és } \\
\text { gimnáziumi oktatás/ } \\
\text { állami }\end{array}$ & $\begin{array}{l}\text { Direkt költségvetési } \\
\text { inputfinanszírozás a } \\
\text { tankerületi iskolafenntartó } \\
\text { központok számára + célhoz } \\
\text { kötött kiegészítő támogatások }\end{array}$ & $\begin{array}{l}\text { - Fizetések/átlagfizetések } \\
\text { - Müködési kiadások/előző évi } \\
\text { bázis } \\
\text { - Ingyenes tankönyv és } \\
\text { gyermekélelmezés/tanulólétszám } \\
\text { („fejkvóta”) }\end{array}$ \\
\hline $\begin{array}{l}\text { Általános iskolai és } \\
\text { gimnáziumi oktatás/ } \\
\text { egyházi }\end{array}$ & $\begin{array}{l}\text { A direkt költségvetési } \\
\text { inputfinanszírozás (fizetések) } \\
\text { és normatív finanszírozás } \\
\text { (müködési költségek) } \\
\text { kombinációja az egyházi } \\
\text { fenntartó számára + célhoz } \\
\text { kötött kiegészítő támogatások } \\
\text { + egyházak egyedi oktatási } \\
\text { célú támogatása }\end{array}$ & $\begin{array}{l}\text { - Fizetések/átlagfizetések } \\
\text { - Vallásoktatás költségeinek } \\
\text { finanszírozása/átlagfizetések } \\
\text { - Müködési kiadások/ } \\
\text { tanulólétszám („,fejkvóta”) } \\
\text { - Ingyenes tankönyv és } \\
\text { gyermekélelmezés/tanulólétszám } \\
\text { („fejkvóta”) } \\
\text { - Nem célhoz kötött egyedi } \\
\text { oktatási támogatások/egyházi } \\
\text { fenntartók által utólag benyújtott } \\
\text { költségvetés }\end{array}$ \\
\hline $\begin{array}{l}\text { Általános iskolai és } \\
\text { gimnáziumi oktatás/ } \\
\text { országos kisebbségi } \\
\text { önkormányzati }\end{array}$ & $\begin{array}{l}\text { A direkt költségvetési } \\
\text { inputfinanszírozás (fizetések) } \\
\text { és normatív finanszírozás } \\
\text { (működési költségek) } \\
\text { kombinációja a kisebbségi } \\
\text { önkormányzatok számára } \\
\text { + célhoz kötött kiegészítő } \\
\text { támogatások }\end{array}$ & $\begin{array}{l}\text { - Fizetések/átlagfizetések } \\
\text { - Müködési kiadások/ } \\
\text { tanulólétszám (,fejkvóta”) } \\
\text { - Ingyenes tankönyv és } \\
\text { gyermekélelmezés/tanulólétszám } \\
\text { (,fejkvóta”) }\end{array}$ \\
\hline $\begin{array}{l}\text { Általános iskolai és } \\
\text { gimnáziumi oktatás/ } \\
\text { egyéb magán }\end{array}$ & $\begin{array}{l}\text { Direkt költségvetési } \\
\text { inputfinanszírozás (fizetések) } \\
\text { a magánfenntartó számára } \\
\text { + célhoz kötött kiegészítő } \\
\text { támogatások }\end{array}$ & $\begin{array}{l}\text { - Fizetések/átlagfizetések } \\
\text { - Ingyenes tankönyv és } \\
\text { gyermekélelmezés/tanulólétszám } \\
\text { („fejkvóta”) }\end{array}$ \\
\hline $\begin{array}{l}\text { Középfokú szakképzés/ } \\
\text { állami, egyházi és } \\
\text { egyéb magán }\end{array}$ & $\begin{array}{l}\text { Decentralizált } \\
\text { inputfinanszírozás a } \\
\text { szakképzési központok } \\
\text { számára (fizetések és } \\
\text { müködési kiadások) + célhoz } \\
\text { kötött kiegészítő támogatások }\end{array}$ & $\begin{array}{l}\text { - Fizetések átlagfizetések alapján } \\
\text { kalkulálva + egy tanulóra eső } \\
\text { müködési kiadások/évente } \\
\text { megállapított finanszírozott } \\
\text { tanulói létszámkeret } \\
\text { - Ingyenes tankönyv és } \\
\text { gyermekélelmezés/tanulólétszám } \\
\text { („fejkvóta”) }\end{array}$ \\
\hline
\end{tabular}




\section{Finanszírozási ösztönzök: eltérő mértékü támogatások}

Részben megbízható adatok hiányában, részben pedig a különböző tulajdonosi körök eltérő rendszerü finanszírozása miatt az állami és magániskolákra fordított költségvetési kiadások igen nehezen hasonlíthatók össze. Mindazonáltal az egy före eső támogatások tekintetében mód van néhány összehasonlításra (10. táblázat).

Amikor 2012-ben a KLIK költségvetését első alkalommal különítették el, a pedagógusok bérére fordított kiadások tervezésének alapja egységesen (fenntartóktól függetlenül) az éppen érvényes pedagógus bértábla alapján történt. Ennek következtében a személyi kiadások tekintetében nem keletkeztek jelentős különbségek az állami és a különböző magániskolák között. Ezzel szemben azonban ugyanebben az évben az állami iskolák dologi müködési kiadásainak finanszírozása hatalmas összeggel, bizonyos becslések szerint 120 milliárd forinttal csökkent, miközben az egyházi iskolák normatív működési támogatása nem csökkent. Azóta az állami iskolák müködési kiadásainak finanszírozása minden évben ezen a rendkívül alacsony szinten maradt. A Költségvetési Felelösségi Intézet számításai alapján jól látszik, hogy a 2012-ben kialakult finanszírozási szakadék jelenleg is fennáll, sőt, 2018-ban tovább szélesedett. Az intézet kalkulációja szerint ahhoz, hogy az állami iskolák dologi kiadásai ugyanolyan szinten legyenek finanszírozva, mint az egyházi iskoláké, 2016-ban 79,2 milliárd forint, 2017-ben pedig már 112,5 milliárd forint többlettámogatásra lett volna szükség.

10. táblázat. Az állami és egyházi iskolák dologi müködési kiadásainak költségvetési támogatása (a szakképző intézmények támogatása nélkül, Forrás: Költségvetési Felelősségi Intézet ${ }^{5}$ )

\begin{tabular}{|c|c|c|c|c|}
\hline & \multicolumn{2}{|c|}{$\begin{array}{l}\text { 2016/2017 tanév } \\
\text { (tény) }\end{array}$} & \multicolumn{2}{|c|}{$\begin{array}{l}\text { 2017/2018 tanév } \\
\text { (költségvetési terv) }\end{array}$} \\
\hline & $\begin{array}{l}\text { Egyházi } \\
\text { iskolák }\end{array}$ & $\begin{array}{l}\text { Állami } \\
\text { iskolák }\end{array}$ & $\begin{array}{l}\text { Egyházi } \\
\text { iskolák }\end{array}$ & $\begin{array}{l}\text { Állami } \\
\text { iskolák }\end{array}$ \\
\hline $\begin{array}{l}\text { Tanulólétszám (fö) (fajlagos } \\
\text { finanszírozási alap az SNI } \\
\text { tanulók magasabb támogatásával } \\
\text { korrigálva) }\end{array}$ & 207505 & 774243 & 207505 & 774243 \\
\hline $\begin{array}{l}\text { Visszatérő működési költségekre } \\
\text { fordított költségvetési kiadás (millió } \\
\text { Ft.) }\end{array}$ & 33200 & 44636 & 41501 & 42339 \\
\hline $\begin{array}{l}\text { Visszatérő működési költségekre } \\
\text { fordított egy tanulóra eső } \\
\text { költségvetési kiadás (Ft.) }\end{array}$ & 160000 & 57651 & 200000 & 54684 \\
\hline $\begin{array}{l}\text { Az állami iskolák egy tanulóra eső } \\
\text { müködési költségvetési támogatása } \\
\text { az egyházi iskolák kiadásainak } \\
\text { arányában. }(\%)\end{array}$ & \multicolumn{2}{|c|}{36,0} & \multicolumn{2}{|c|}{27,3} \\
\hline
\end{tabular}

5 https://168ora.hu/itthon/valami-nagyon-eltorzult-negyszer-tobb-penzt-ad-az-allam-az-egyhazi-iskolaknak-mint-a-sajatjainak-5029 
Az egy tanulóra eső kiadások összehasonlítására az MTA Közgazdaságtudományi Intézete által kiadott $A$ közoktatás indikátorrendszere 2017 kötetben szereplö, 2016-ra vonatkozó finanszírozási adatok alapján van módunk. Amint az adatokból jól látszik, az általános iskolai és gimnáziumi oktatásban a személyi kiadások támogatásában 2016ban sem voltak jelentős különbségek az állami, egyházi és nem egyházi magánoktatásban (4. ábra). Ezzel szemben jelentős különbségek alakultak ki az egyéb személyi és működési kiadások tekintetében. A magániskolák magasabb személyi kiadásait két ok magyarázza. Az első az, hogy amikor az állami iskolák pedagógusai a KLIK munkavállalói lettek, új szerződésük megszüntetett minden, korábban az önkormányzatok által biztosított, béren kívüli kiegészítő juttatást, amely ebben a szektorban sok esetben jelentős mértékü jövedelemcsökkenést eredményezett. A magániskolák nagyobb gazdálkodási önállóságának köszönhetően ezek a juttatások a magániskolákban többnyire megmaradtak. A másik ok az, hogy az egyházi és egyéb magániskolák tulajdonosainak az alapfinanszírozásba épített költségvetési támogatáson kívül is vannak bérekre fordítható saját bevételeik. Az egyházi iskolák számára ezt az évente több alkalommal eseti döntésekkel megítélt jelentős kormányzati plusztámogatás biztosítja, az egyéb magániskolák pedig tipikusan tandíjakból és pályázati támogatásokból jutnak kiegészítő forrásokhoz. Az egyházak oktatási feladatai ellátásához nyújtott pluszforrások felhasználása az egyes egyházak belső forrásfelhasználásáról semmilyen nyilvános információ nem elérhető, ezért az egyházak gazdálkodása pont olyan átláthatatlan, mint a tankerületi központoké. Mindösszesen az egyházaknak módjukban áll több pedagógust és pedagógiai munkát segítő szakembert alkalmazni, mint az állami iskoláknak, valamint magasabb béreket tudnak fizetni.

Az iskolarendszerű szakképzésben az egy tanulóra eső kiadások éppen ellenkező mintát mutatnak. Eredetileg a volt önkormányzati tulajdonban lévő szakképző intézmények az általános iskolákkal és a gimnáziumokkal együtt a KLIK-be olvadtak be. 2015-ben a szakképzés felügyelet a Nemzetgazdasági Minisztériumhoz került. Ezt követően a szakképző intézmények müködtetésére regionális szakképzési központokat hoztak létre, melyek lényegében más intézmények müködtetésére kijelölt szakképző iskolák voltak. Az egyes szakképző iskolák nem kapták vissza önállóságukat, a szakképzési központok azonban bizonyos gazdálkodási, intézményi és szakmai autonómiát kaptak. Annak érdekében, hogy a központok számára lehetővé tegyék az önálló gazdálkodás pénzügyi mozgásterét, azok költségvetését a korábbi finanszírozási szinthez képest jelentős mértékben megnövelték, melynek következtében az állami szakképző iskolák egy tanulóra eső kiadásai lényegesen magasabbak lettek, mint az általános képzést nyújtó állami iskoláké. Ugyanez a különbség alakult ki az állami szakképző intézmények és a nem szakképzési központokba szervezett módon müködő magánintézmények között, mely utóbbiak finanszírozási szintje alacsonyabb. (A nem egyházi magánintézmények lényegesen alacsonyabb finanszírozása a szakképzésben ezen intézményi körnek az iskolarendszerü szakképzésből való kiszorítását célzó politika részét képezi.) 
Ercse Kriszta - Radó Péter: A magyar közoktatásban zajló privatizáció és annak hatásai

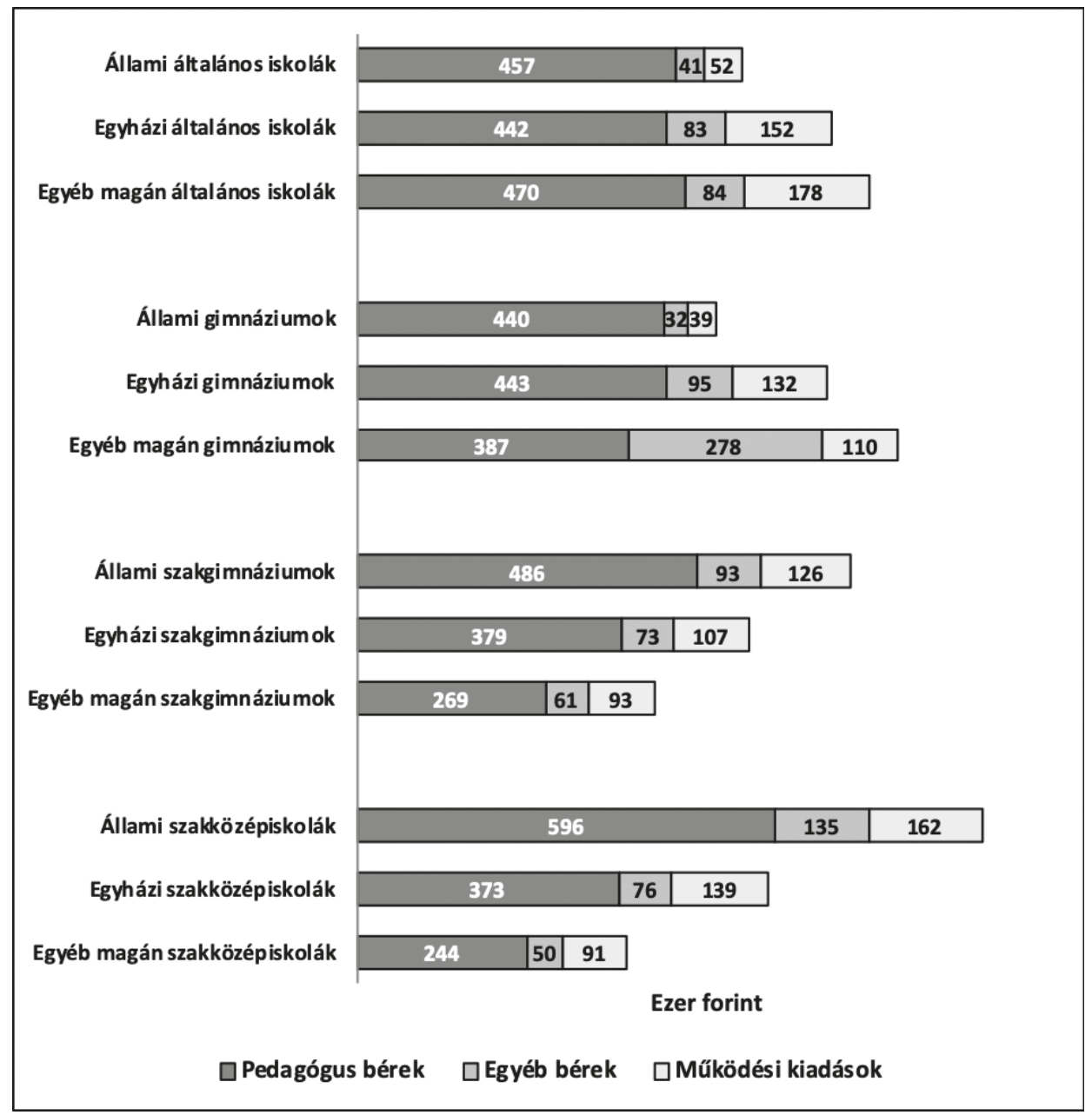

4. ábra. Egy tanulóra eső kiadások az állami, egyházi és egyéb magán fenntartású iskolákban 2016-ban (ezer forint, Forrás: Varga, 2018)

\section{A különbözö eszközök összegzödö hatása}

Az eddigiekben ismertetett oktatáspolitikai eszközök megváltoztatták az oktatás legfontosabb helyi szereplői, különösen a helyi önkormányzatok és a szülök érdekeit.

Az egyházi iskolák nagyobb szakmai mozgástere és a magasabb finanszírozás miatt jobb felszereltsége a jobb iskola képét alakítja ki, ami vonzóbbá tette azokat a középosztályi szülők számára. Másfelől a szegény és roma tanulók magas - és növekvő - aránya az állami iskolákban a rossz oktatási minőség látszatát kelti. Mindezek következtében az egyházi iskolák megengedhetik maguknak, hogy szelektív beiskolázási politikát folytassanak, ami - a szülői döntések felől nézve - egyfajta szelekciós spirált generálva tovább növelte vonzerejüket a magasabb státuszú családok körében. Noha az önkormányzati iskolák egyházaknak való átadását nem a szülők kezdeményezték, ezek a vélt elönyök elegendőek voltak arra, hogy igen sok esetben a szülők hozzájáruljanak gyermekük iskoláinak privatizációjához (Ercse, 2018). Abban a nagyon kevés esetben, amikor az 
iskola átadásában szülői igény is megjelent, ebben szerepet játszott a roma és többségi közösség közötti konfliktus, ami felerősítette a szeparációs hajlandóságot. A nem egyházi magániskola-hálózat utóbbi években újra megfigyelhető csekély növekedése mögött egyértelmüen az a szülöi igény áll, hogy gyerekük számára alternatívát keressenek a drasztikusan romló minőséget nyújtó állami iskolákkal szemben.

Az iskolák egyházaknak való átadását számos esetben vagy önkormányzatok kezdeményezték, vagy pozitívan reagáltak az erre irányuló kormányzati vagy egyházi „megkeresésre". Ennek legfontosabb oka az önkormányzati finanszírozás korábbi években egyre jobban súlyosbodó problémái volt. 2006-tól kezdve a magas költségvetési hiány, majd pedig 2008-tól a válság hatása miatt a helyben nyújtott közszolgáltatások állami költségvetési támogatása drasztikus mértékben csökkent. A kieső bevételeket számos önkormányzat hitelek felvételével pótolta, melyek egy részét uniós programok önrészére és folyó kiadásaik (például oktatási kiadásaik) finanszírozására fordította. Mindez 2009-2010-re az önkormányzatok jelentős eladósodásához vezetett, ami igen sok településen kétségessé tette az iskolák stabil finanszírozását. Ennek következtében - valamint a kormányzat által alkalmazott ösztönzők hatására - 2011-ben és 2012-ben igen sok önkormányzat kezdett tárgyalásokat az egyházakkal abban a reményben, hogy egyes iskolák átadása csökkenti pénzügyi terheiket. Ebben erőteljesen közrejátszott, hogy a köznevelési törvény koncepciójának kiszivárgása és a Széll Kálmán terv 2011. márciusi elfogadása után látszólag csupán az egyházak voltak abban a helyzetben, hogy garantálják az iskolák megfelelő finanszírozását és az általuk nyújtott szolgáltatás minőségének megörzését. A 2013-as ,államosítást” követően további iskolák egyházaknak való átadásában már a KLIK müködött közre.

Ami a nagyobb keresztény egyházak viselkedését illeti, azt - a hagyományos missziós célokon túl - alapvetően két megfontolás határozta, illetve határozza meg. Egyrészt a Katolikus, Református és Evangélikus Egyházak vezetőinek jelentős része úgy véli, hogy a „történelmi egyházaknak” vissza kell nyerniük a két világháború közötti elitképzésben betöltött szerepüket. Ezek az egyházak a rendszerváltást követően folyamatosan arra törekedtek, hogy helyreállítsák korábbi kiterjedt iskolahálózatukat, de megfelelően erős szülői igények hiányában a 2010 előtti két évtizedben ez csak töredékesen valósult meg. Másrészt az egyházi vezetők körében változatlanul erős az a meggyőződés, hogy közel fél évszázados elnyomás után a magyar állam jóvátétellel tartozik az egyházaknak. Mind a két megfontolás jelentős támogatottságot élvez a 2010 óta kormányzó koalíció politikusai körében. Ez a támogatás különösen erős volt a 2012-2018 közötti időszakban, amikor az oktatásért felelős miniszter egy református lelkész volt.

\section{A tulajdonosi szerkezet változásának hatékonyságra gyakorolt hatása}

A legfontosabb hatékonysági kérdés az oktatásban az oktatási kapacitások és a tanulólétszám közötti egyensúly fenntartása. Az erről szóló adatok az 1990-es rendszerváltás óta eltelt közel három évtized során végig súlyos hatékonysági problémákról tudósítanak, az iskolai kapacitások és a beiskolázott tanulók száma közötti olló folyamatosan rendkívül széles volt. Ennek kialakulása elsősorban a rendszerváltást követő években, 1990-1995 között következett be, melynek fő oka a tanulólétszám csökkenésének és az iskolák száma növekedésének együttes hatása volt. A 2010 utáni időszakban a tanulólétszám lényegében stagnált, az intézmények száma pedig csak csekély mértékben nött, a közoktatási rendszer tovább görgette a már korábban kialakult kapacitásfelesleget. Az 5. ábrán az iskolák számában látszó 2013-as megugrást a KSH statisztikai módszertanában végrehajtott változtatás okozta, a változtatás előtti és utáni adatok nem összehasonlíthatók. 


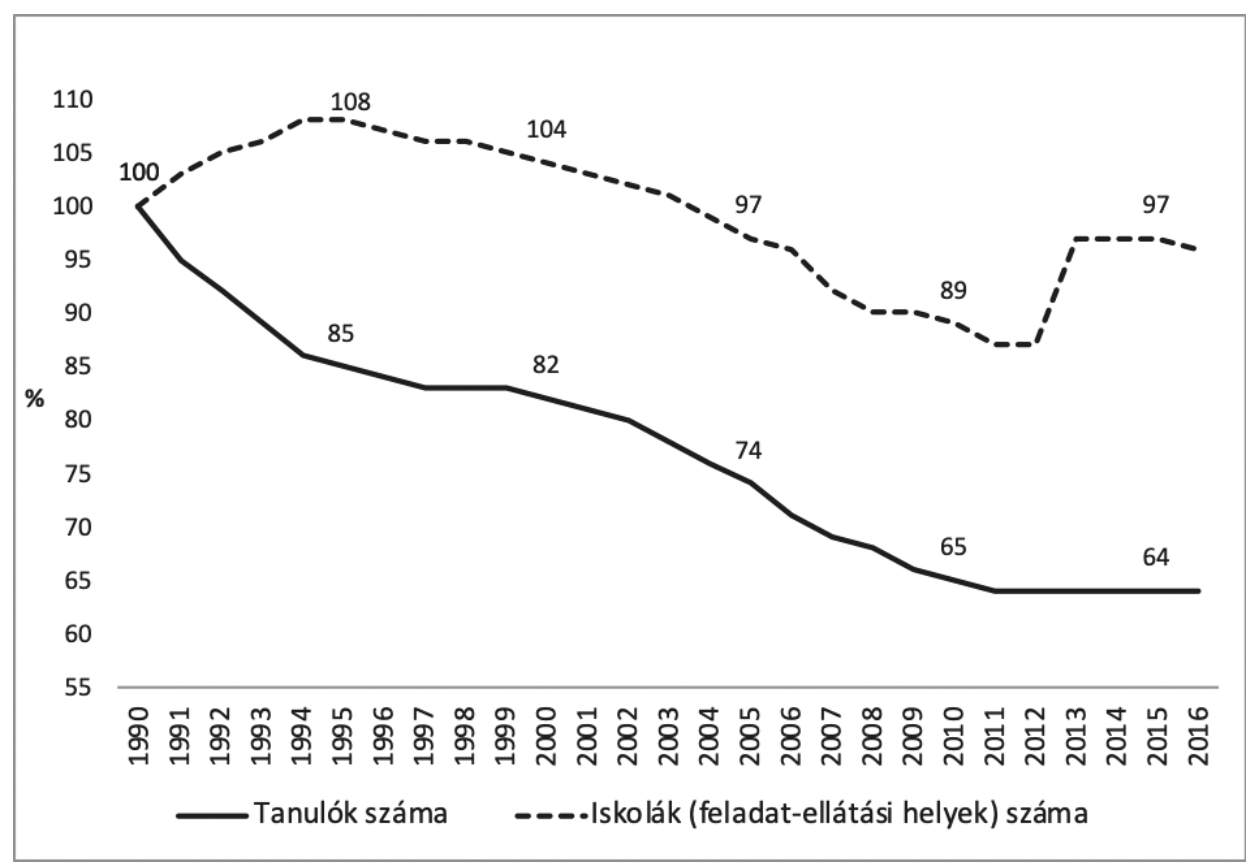

5. ábra. A tanulók és az iskolai feladatellátási helyek számának alakulása a rendszerváltás óta $(1990=100 \%$, Forrás: KSH)

2011 előtt a kapacitások és tanulólétszám közötti egyensúly fenntartásának legfontosabb eszköze a különböző bevételeikkel önállóan gazdálkodó önkormányzatok viselkedésének finanszírozási ösztönzőkkel történő befolyásolása volt. A decentralizált normatív finanszírozás lehetővé tette olyan pénzügyi ösztönzők alkalmazását, amelyek az önkormányzatokat érdekeltté tették a hatékonyság bizonyos minimumának biztosításában. E tekintetben általában a legkisebb ellenállás irányába haladtak, sokkal inkább az indítható osztályok számát korlátozták, semmint az intézmények számát. (Egy bizonyos mértékig ez az eljárás képes kordában tartani a hatékonyságromlást, mert az oktatási kiadások mértékét nem elsősorban a tanulók, vagy az iskolák száma, hanem a tanulócsoportok száma határozza meg.) A politikai költségek mérséklése érdekében iskolák bezárására vagy összevonására szinte kizárólag az önkormányzati választási ciklusok első évében, utoljára 2007-ben került sor.

2011 után gyökeresen megváltozott a helyzet. A bürokratikus központi irányításra és az inputfinanszírozásra való átállás következtében a kormányzás új rendszerében a szó valódi értelmében egyetlen irányítási szereplő sem gazdálkodik, s nincs mód finanszírozási ösztönzők alkalmazására sem. A költségvetési forráskivonás hatására a tankerületi központok erösen korlátozzák az indítható párhuzamos osztályok számát, iskolákat azonban nem zárnak be. (A helyi iskolahálózatok átszervezése nem pénzügyi gazdálkodási, hanem hatékonysági szempontokra tekintettel lévő politikai döntés. Ilyen döntéseket tankerületi tisztviselők nem hoznak.) Mindezek hatására az állami iskolahálózat lényegében befagyott. Mivel a tanulólétszám az utóbbi években stagnált, azok a főleg egyházi magániskolák, melyek nem meglévő iskola átvételével, hanem új iskola létrehozásával, vagy korábban bezárt kisiskolák újranyitásával jöttek létre, lényegében nettó hatékonyságromlást eredményeztek. Ez abban az esetben is így van, ha egy új iskola létrehozása után a településen müködő összes iskolában indított osztályok száma nem változik, ugyanis az iskolaméretek csökkenése is növeli a fajlagos (egy tanulóra eső) kiadásokat. 
Ez a hatékonyságromlás jól kimutatható az ezt jelző legfontosabb indikátor, a tanárdiák arány alakulásában (6. ábra). Az általános iskolai oktatásban az egyházi tulajdonban lévő magániskolák hálózatának bővülése azt eredményezte, hogy az egyházi iskolák nagyon nagy számban szívtak el tanulókat az állami iskolarendszerből. Ez az egyházi iskolákban enyhe hatékonyságjavulást, az állami iskolahálózatban viszont drasztikus hatékonyságromlást idézett elő. A tanár-diák arány 2016-ban az egyházi iskolákban 10,4, az állami iskolákban csupán 9,7 volt. A nem egyházi magániskolákban ugyanebben az időszakban a tanár-diák arány 6,8-ról fokozatosan 9-re növekedett - e mutató alapján a hatékonyságuk megközelítette az állami iskolákét. Összehasonlítás gyanánt: 2014-ben ez az arány az OECD országokban átlagosan 15 volt, Csehországban 19, Szlovákiában 17 , Lengyelországban és Magyarországon pedig csupán 11 (OECD, 2018).

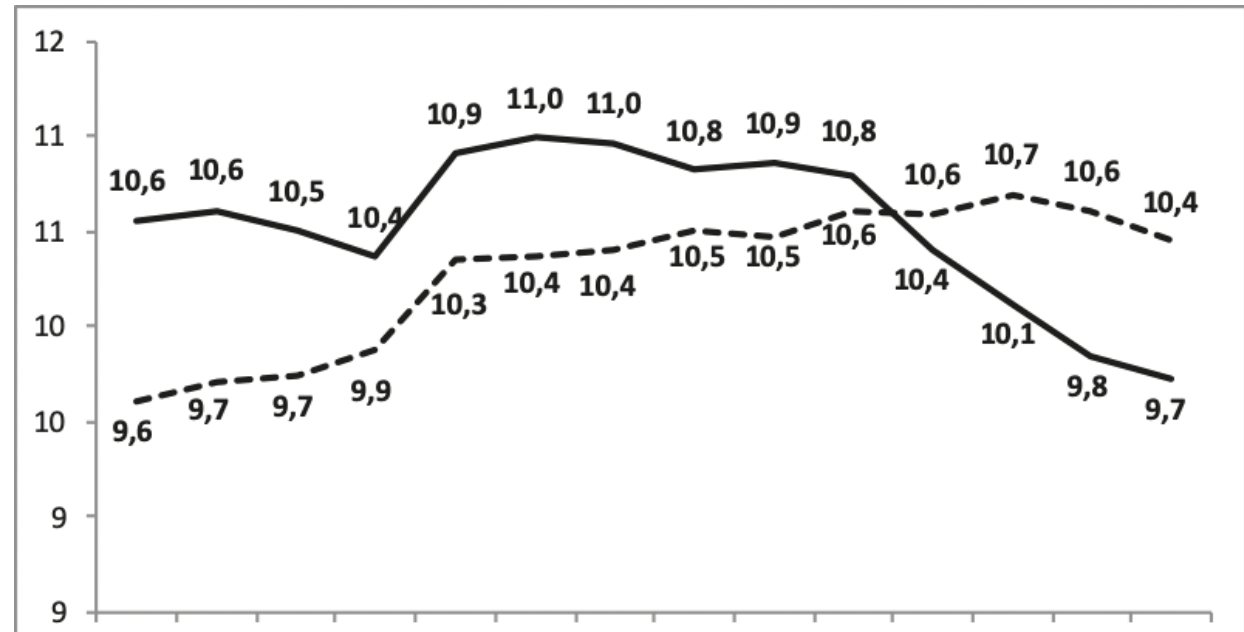

20032004200520062007200820092010201120122013201420152016

Önkományzati/állami iskolák _- - - Egyházi iskolák

6. ábra. A tanár-diák arány változása a közösségi és egyházi tulajdonban lévö általános iskolákban (Forrás: Varga, 2018)

2011 óta mindkét szakképző intézménytípusban szintén nagyon jelentős hatékonyságromlás zajlott le (7. ábra). A tanár-diák arány 2011 és 2016 között a szakgimnáziumokban 12,9-röl 10,2-re, a szakközépiskolákban 13,7-ről 11-re csökkent. A szakképzésben a demográfiai hatások mellett a hatékonyságromlás elsődleges oka a kormányzat szándékaival ellentétes szülői és tanulói továbbtanulási döntések megváltozó mintázata: az iskolarendszerü szakképzés általános oktatási tartalmának radikális szükítése óta nő a gimnáziumok iránti, s csökken a szakképző intézmények iránti érdeklődés. A nem egyházi magánintézmények jelentős részének kiszorítása a szakképzésből ezen a helyzeten nem javított, ugyanis az egyházi szakképző iskolahálózat növekedése bőségesen ellensúlyozta annak hatékonyságjavító hatását. Mivel a kormányzat jelentős erőfeszítéseket tesz a továbbtanulási trend megfordítása, a tanulók nagyobb hányadának a szakképzés felé terelése érdekében, fel sem merült a szakképzési intézményhálózat racionalizálása, fölöslegessé vált kapacitásainak leépítése. 


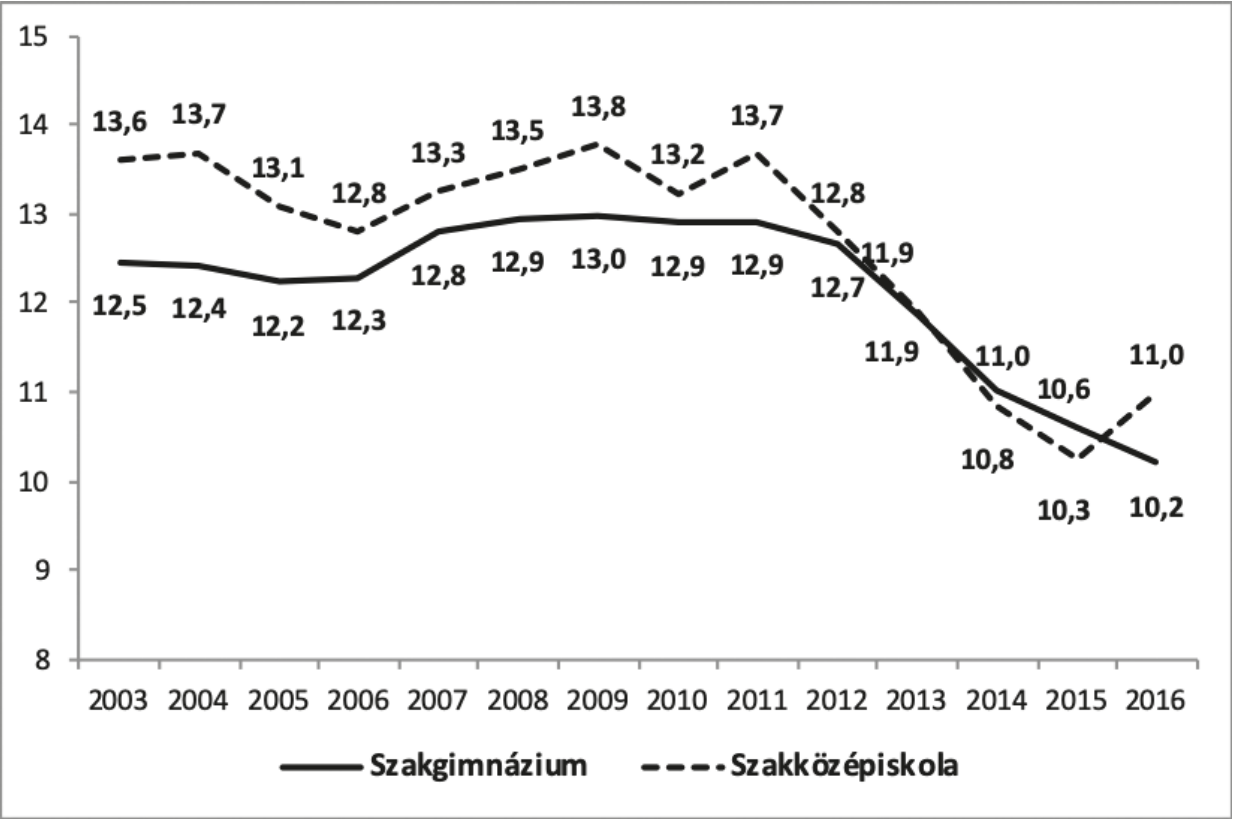

7. ábra. A tanár-diák arány alakulása az iskolarendszerü szakképzésben (Forrás: Varga, 2018)

Mindezek a változások azt eredményezték, hogy a magyar közoktatásban - a gimnáziumi oktatás kivételével - fölösleges iskolai kapacitások nagy tömege jött létre. A fel nem töltött férőhelyek számának alakulásáról csupán a középfokú oktatási intézményekről van adatunk (8. ábra). A férőhely-kihasználtság adatai ugyanazt a súlyos hatékonyságromlást jelző trendet vázolják fel, mint a tanár-diák arányok változása. A tanulói összlétszám csökkenésének ellenére a szerkezetváltó gimnáziumok megőrizték féröhelyeik feltöltöttségének korábbi 90 százalék körüli szintjét, a négy évfolyamos iskolákban pedig ez az arány stabilan 75 százalék körül alakult. A szakképző iskolákban azonban szinte katasztrofális mértékü kapacitásfelesleg jött létre: napjainkban a szakgimnáziumok féröhelyeinek alig több mint fele, a szakközépiskolák féröhelyeinek pedig alig több mint harmada van kihasználva. 


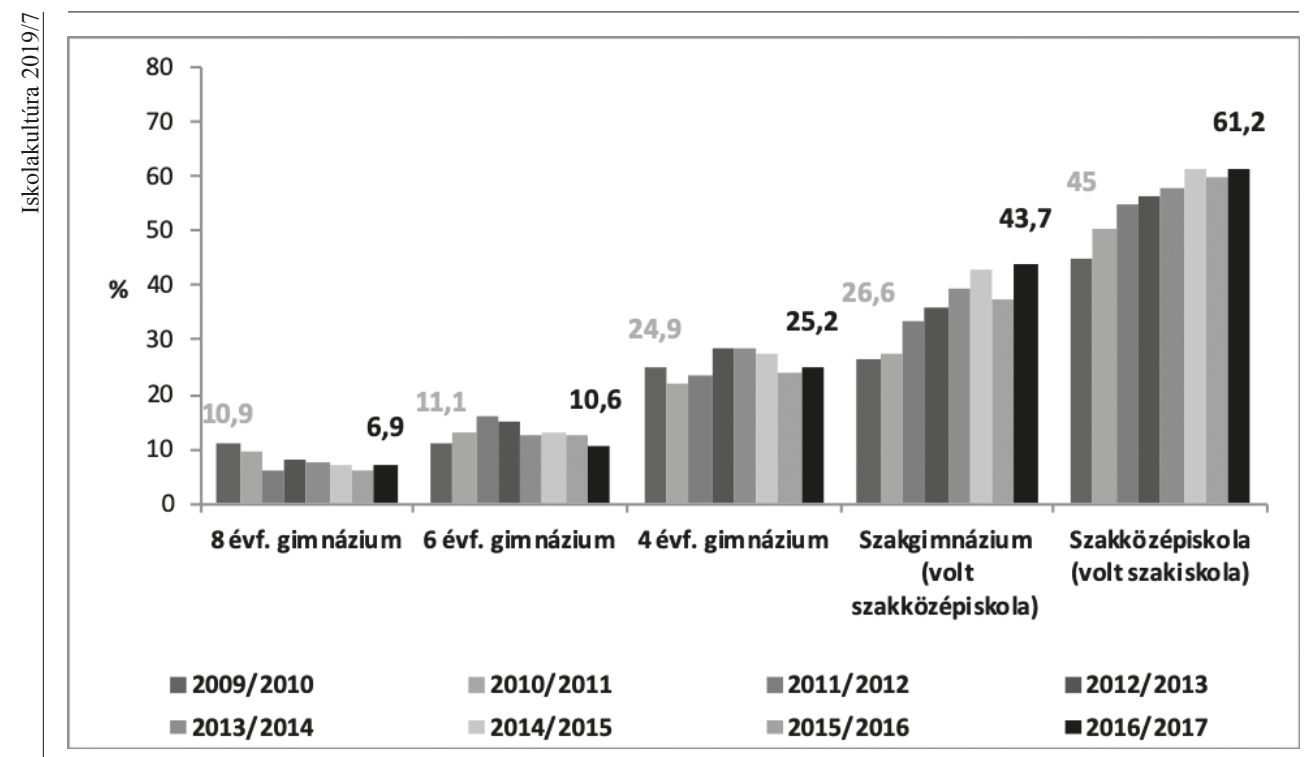

8. ábra. A fel nem töltött férőhelyek arányának változása a középfokú oktatásban, 2009-2016 (Forrás: Oktatási Hivatal)

A kapacitásfelesleg növekedése által okozott hatékonyságromlás másik jele a 100 fósnél kisebb iskolákban oktatott tanulók arányának emelkedése (9. ábra). Ez az emelkedés az általános iskolai oktatásban lényegében az egyházi iskolahálózat rövid idő alatt lezajlott gyors bővülésének egyszeri hatása, a szakképzésben, ezen belül különösen a szakközépiskolákban viszont egy tartósabb és mértékét tekintve is súlyosabb hatékonyságromlás következménye.

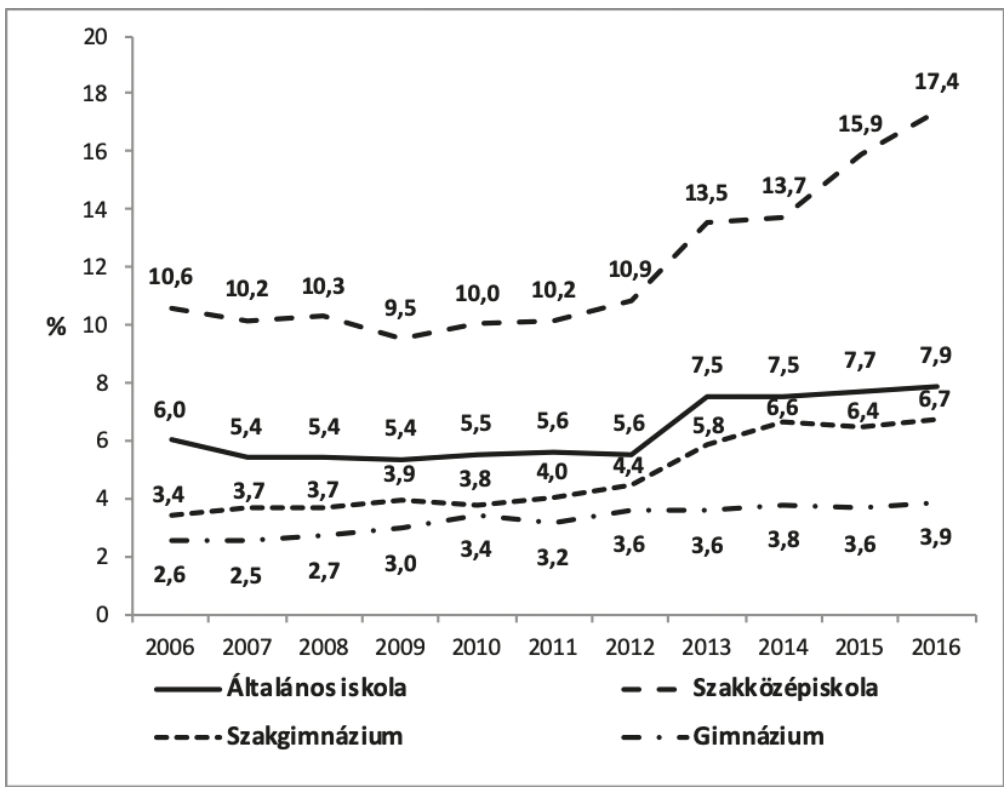

9. ábra. A száz fönél kisebb létszámú iskolákban tanulók aránya (Forrás: Varga, 2018) 
Összességében elmondható, hogy az utóbbi években a közoktatásban zajló privatizáció, pontosabban a privatizáció következtében az iskolahálózat továbbaprózódása jelentős mértékben súlyosbította a korábban is megfigyelhető hatékonysági problémákat. Jelenleg a magyar közoktatásban egyszerre érvényesül a súlyos pénzügyi és humánerőforráshiány és a rendkívül nagy erőforrás-pazarlás. Az erőforrás-felhasználás hatékonyságának romlásában - a demográfiai folyamatok és a középfokon átrendeződő továbbtanulási prioritások mellett - egyaránt komoly szerepet játszanak az ,államosítás” során létrejött új kormányzati irányítási rendszer diszfunkciói és az egyházi iskolák térnyerésével megvalósuló privatizáció is.

\section{A tulajdonosi szerkezet változásá- nak minőségre és eredményességre gyakorolt hatása}

Mint köztudott, a magyar közoktatás teljesítménye 2009 óta minden fontos, részvételre és tanulási teljesítményekre vonatkozó indikátor alapján példátlanul nagymértékben romlott. Jelentős mértékben csökkent a közoktatásban tanuló tizenhét és tizennyolc évesek aránya, nőtt a korai iskolaelhagyók aránya, az OECD PISA méréseinek eredményei szerint drasztikusan romlott a 15 évesek szövegértési, matematikai és természettudományos kompetenciák terén mért teljesítménye, s mindhárom kompetenciaterületen jelentősen megugrott a kudarcot vallók aránya. Fontos kérdés, hogy a tulajdonosi szerkezet változásával kapcsolatos két ellentétes folyamat (az „államosítás” és a privatizáció) közül melyik járult hozzá inkább a közoktatás eredményességének romlásához.

A PISA mérés eredményei tulajdonosi háttér szerinti bontásban nem állnak rendelkezésre, ezért a magyar kompetenciamérés eredményeinek alakulásából kell kiindulnunk. Mint a 10. és 11. ábrákon látható, 2010 óta a magyar közoktatás összteljesítményét meghatározó állami és egyházi iskolahálózat eredményessége közötti különbség 2013-ig szükült, ugyanis az egyházi iskolák átlagos teljesítménye jobban romlott, mint az államiaké. Ezt követően mindkét területen a két szektor közötti teljesítménykülönbség mértéke lényegében nem változott. (A nem egyházi magániskolák teljesítményének ingadozása alapvetően e szektor intézményrendszere összetételének folyamatos változásával függ össze, eredményességükről annak kis mérete és nagy belső változatossága miatt nem vonhatók le messzemenő következtetések.)
Összességében elmondható, hogy az utóbbi években a közoktatásban zajló privatizáció, pontosabban a privatizáció következtében az iskolahálózat továbbaprózódása jelentós mértékben súlyosbitotta a korábban is megfigyelhetố hatékonysági problémákat. Jelenleg a magyar közoktatásban egyszerre érvé-

nyesül a súlyos pénzügyi és humánerôforrás-hiány és a rendkivül nagy eróforrás-pazarlás. Az erôforrás-felhasználás hatékonyságának romlásában - a demográfiai folyamatok és a középfokon átrendezôdó továbbtanulási prioritások mellett - egyaránt komoly szerepet játszanak az „államosítás" során létrejött új kormányzati irányitási rendszer diszfunkciói és az egyházi iskolák térnyerésével megvalósuló privatizáció is. 


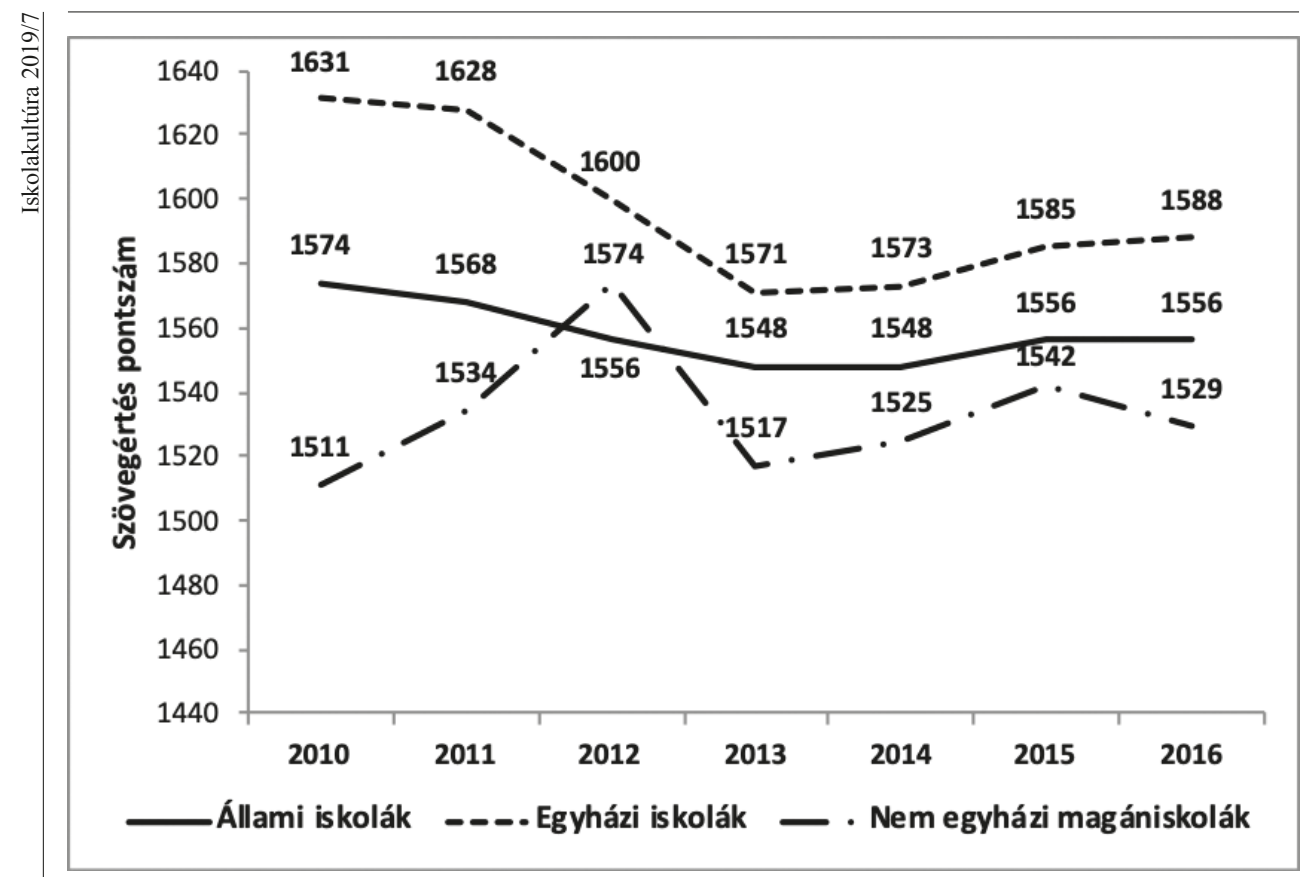

10. ábra. Az egyes tulajdonosi körbe tartozó intézményekben tanuló diákok szövegértés eredményének alakulása (8. évfolyam, 2010-2016, forrás: OKM)

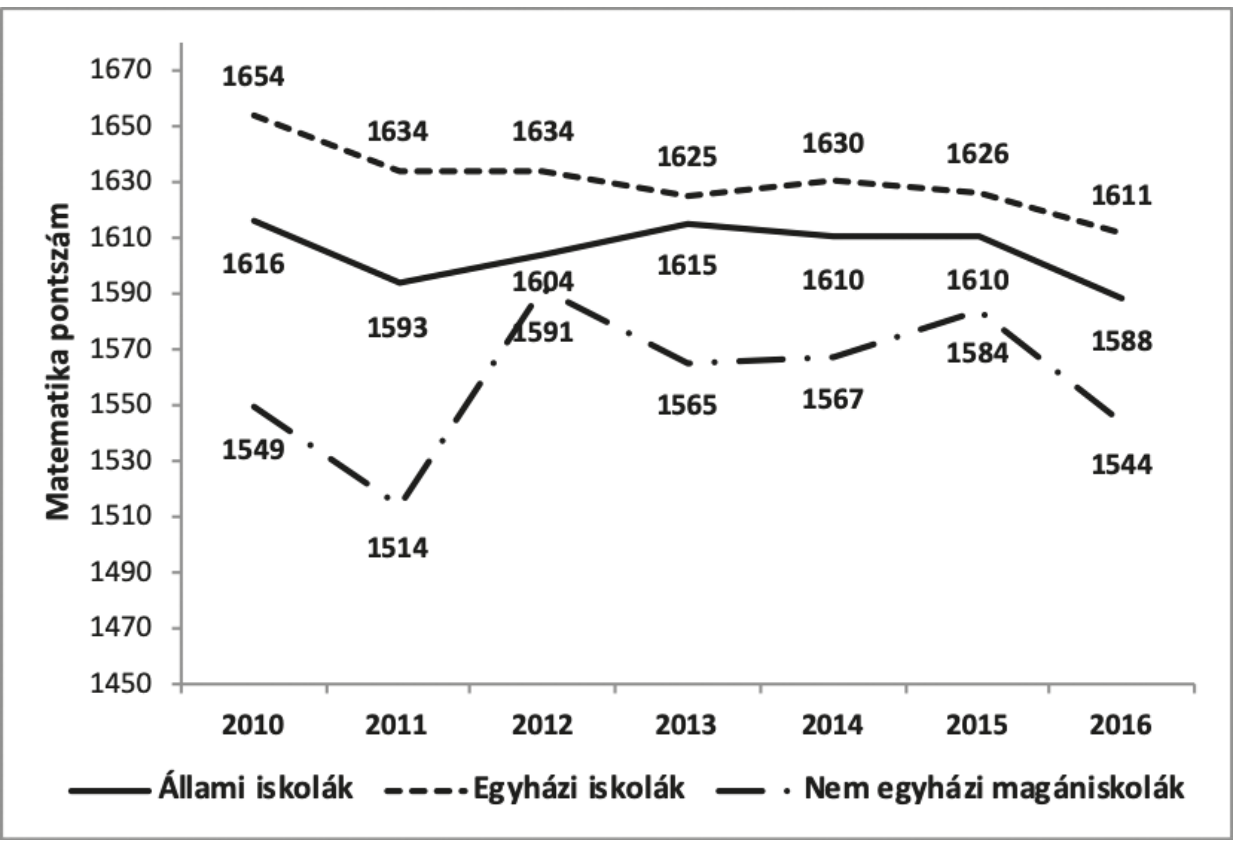

11. ábra. Az egyes tulajdonosi körbe tartozó intézményekben tanuló diákok matematika eredményének alakulása (8. évfolyam, 2010-2016, forrás: OKM) 
Mindazonáltal ezek az adatok egy kicsit megtévesztők, ugyanis a mért teljesítmények változása mögött nem az egyházi iskolák által biztosított oktatás romló minősége áll, hanem az egyházi iskolahálózat expanziója. Arról van szó ugyanis, hogy számos olyan településen kerültek korábban önkormányzati tulajdonban lévő iskolák egyházi tulajdonba, ahol a tanulók átlagos családiháttér-indexe a korábban is egyházi tulajdonban müködő iskolákénál jóval alacsonyabb volt. (Ennek ellenére, mint azt a 12. ábra adatai mutatják, az egyházi iskolák átlagos családiháttér-indexe továbbra is lényegesen magasabb, mint az állami iskoláké.) Mivel Magyarországon a családi háttér hatása a tanulási teljesítményekre nemzetközi összehasonlításban igen magas, az egyházi iskolák kismértékben romló eredményessége teljes mértékben ezzel magyarázható.

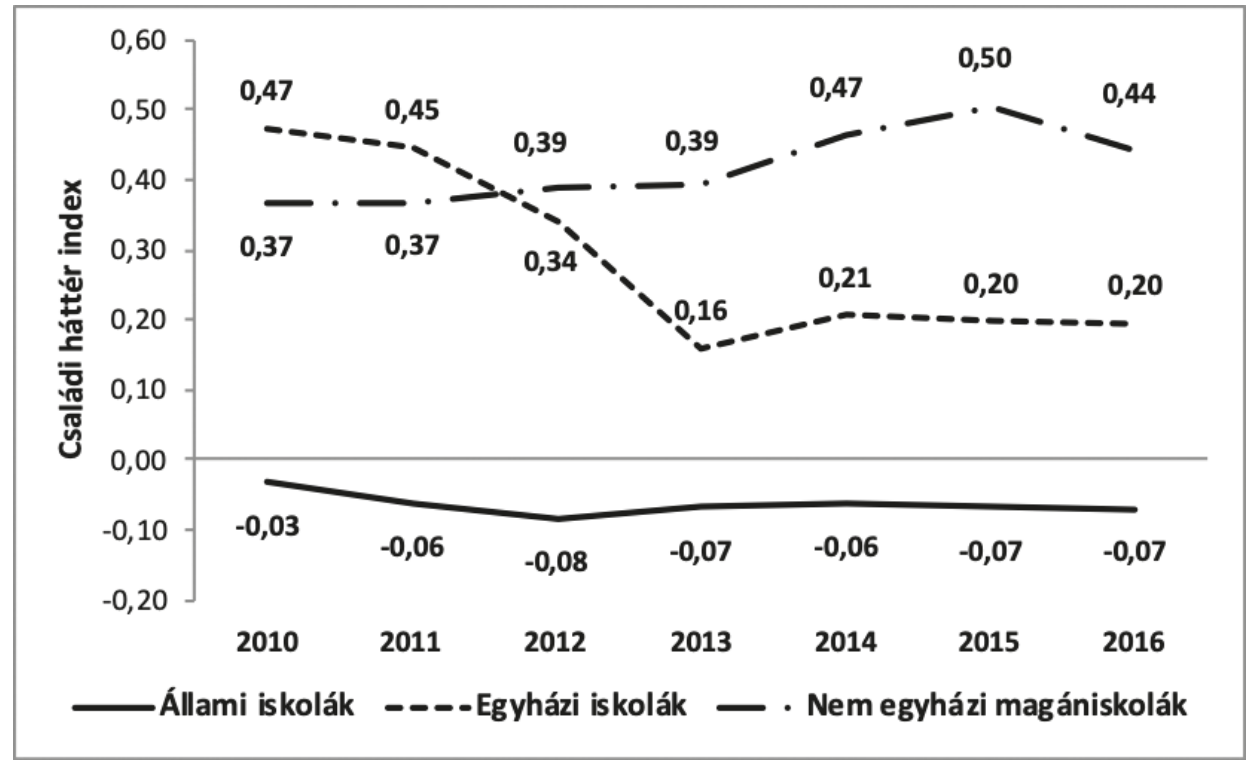

12. ábra. Az egyes tulajdonosi körbe tartozó intézményekben tanuló diákok átlagos családiháttér-indexének alakulása (8. évfolyam, 2010-2016, forrás: OKM)

Fontos tehát látnunk, hogy - mint arról a továbbiakban bőségesen lesz szó - az egyházi iskolahálózatban az átlagos teljesítményromlást okozó átlagos családiháttér-index csökkenés nem az egyházi iskolák szelektivitásának mérséklődésével magyarázható. Egyszerüen arról van szó, hogy az egyházi iskolahálózat bővülése az ország négy szegényebb régiójában (Dél-Dunántúl, Dél-Alföld, Észak-Alföld, Észak-Magyarország) sokkal eröteljesebb volt, mint a többi régióban. Ennek következtében 2010-ben az egyházi iskolahálózat tanulóinak 48,4 százaléka, 2016-ban viszont már 61,8 százaléka került ki a négy régió tanulói közül. Az egyházi tulajdon expanziója tehát olyan területeken volt a legerősebb, ahol nem csupán az alacsony státuszú tanulók aránya magasabb, de a relatíve magasabb státuszú tanulók CSHI indexe is alacsonyabb (Ercse, 2019).

Mindezek az adatok azt bizonyítják, hogy a magyar közoktatás tulajdonosi szerkezetében lezajlott két ellentétes irányú folyamat, az ,államosítás” és a privatizáció közül az utóbbi, az egyházi oktatás térnyerése nem magyarázza a magyar közoktatás teljesítményének drasztikus romlását, annak okait tehát elsősorban az ,államosítás” körülményeiben kell keresnünk. A 2015-ös PISA eredmények elemzése világított rá arra, hogy a magyar diákok teljesítményének romlása mögött nem az egyenlőtlenségek hatásának 
növekedése áll. Az egyenlőtlenségek tanulói teljesítménypontszámban kifejezhető következményének alakulása két indikátor együttes hatásával magyarázható. Az első a magyar tanulók átlagos, a PISA mérésekben az összes országban résztvevő összes tanuló átlagos státuszindexéhez (ESCS) viszonyított változása. A második a státuszkülönbségek pontszámokban kifejezett hatásának (az oktatás hátránykompenzációs képességének) változása. A 2009 és 2015 között két egymást követő PISA mérés során e két indikátor magyar tanulókra vonatkozó értékei egymás hatását kiegyenlítő módon változtak. Ennek következtében az egyenlőtlenségek hatását kiszürő számított eredmények és a mért eredmények közötti különbség a két egymást követő mérés során lényegében változatlan maradt (13. ábra, Radó, 2016).

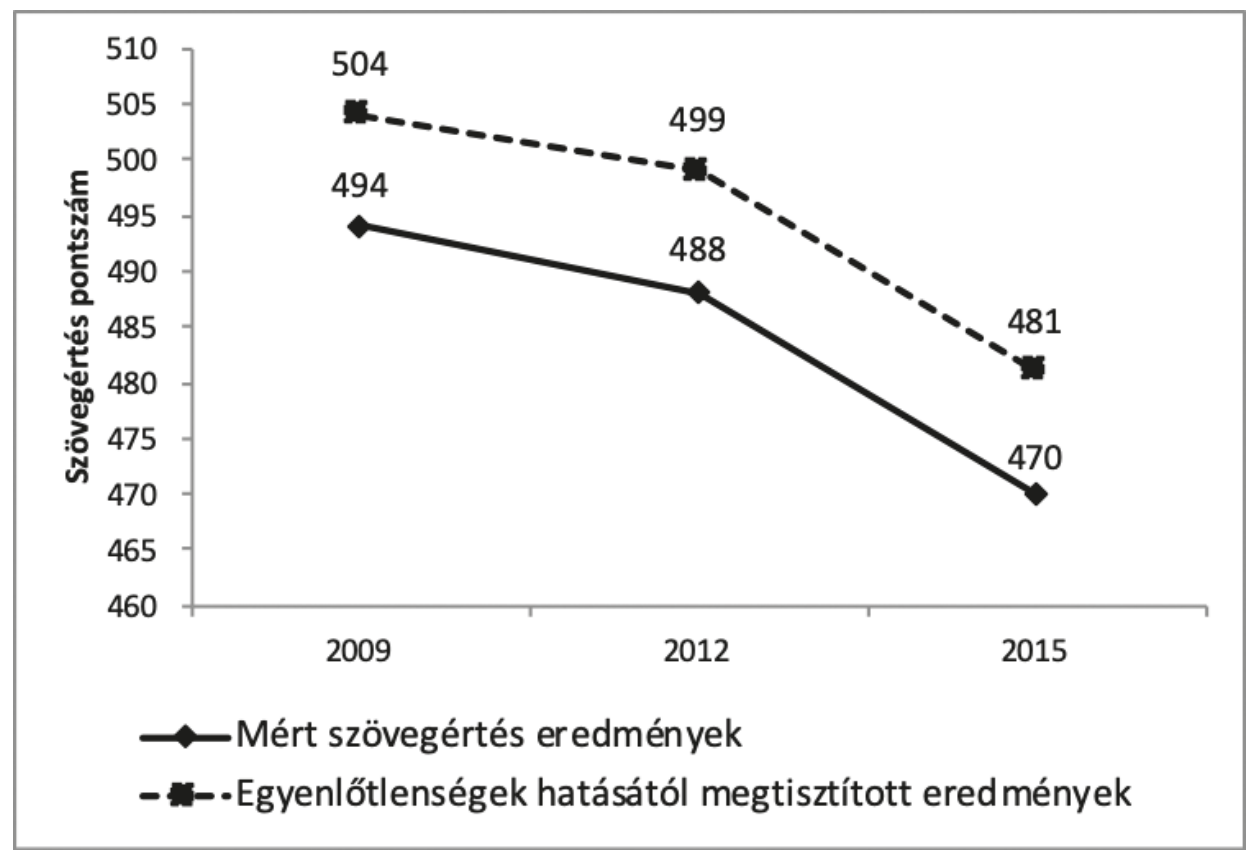

13. ábra. Az egyenlötlenségek számitott hatása a magyar szövegértési eredményekre (PISA 2009-2015, forrás: Radó, 2016)

Egyéb lehetséges magyarázó okok kiszürése után (mint például a mérési módszertan változása, a tanulók nagy száma egészségi állapotának változása, a pedagógus szakma összetételének gyors megváltozása, stb.) az elemzés következtetése az volt, hogy a magyar tanulási teljesítmények romlása mögött egyértelmüen az iskolai oktatás rendkívül gyorsan bekövetkezett minőségromlása áll. Az elemzés által megfogalmazott hipotézis szerint a minőségromlás fő okai abban keresendők, hogy az önkormányzati iskolarendszer ,államosítása" nem egyszerüen tulajdonosváltás révén valósult meg; az együtt járt egy szinte abszurd mértékben centralizált bürokratikus irányítási mechanizmusra való átállással és az iskolák intézményi, gazdálkodási és szakmai autonómiájának szinte teljes felszámolásával. Az állami oktatási hálózat új irányítási rendszere - kiegészülve nagyszámú egyéb rendszerszintű oktatáspolitikai beavatkozás negatív hatásaival - rombolóan hatott azokra az intézményi képességekre, amelyeket a kiegyensúlyozottan magas tanulási teljesítmények biztosítása előfeltételének tartunk (Scheerens és mások, 
2003). Ezek közül is véleményünk szerint különösen a következő intézményi képességek romlása vezetett azonnali, a tanulási eredményekben is kimutatható minőségromláshoz: az iskolán belüli teljesítményorientáció, a tantestületen belüli kohézió és konszenzus, hatékony iskolavezetés, iskolai klíma, iskolai (szervezeti és pedagógiai) értékelési képességek, differenciálásra és inkluzív oktatásra való képesség (Radó, 2016). Még egyszer hangsúlyozni kell: a minőségromlás elsődleges oka nem önmagában a közösségi tulajdonban lévő iskolák tulajdonosváltása, hanem az átfogó rendszer-átalakítás összes változtatásának összegződő hatásmechanizmusa, melyek megvalósítását az önkormányzati iskolahálózat ,államosítása” tett lehetővé.

\section{A tulajdonosi szerkezet változásának egyenlőtlenségekre gyakorolt hatása}

\section{A szelekció hatása}

A magyar oktatási rendszer szelektivitásáról, a szelekció formaváltozatairól több évtizedre visszamenőleg rendelkezünk adatokkal. A szelektivitás eredetének összetett oksági rendszerét Radó (2018) írta le: egyszerre beszélhetünk külső, társadalmi meghatározottságról (különösen: szeparációs igény) és az oktatáson belüli tényezőkről (szegényes pedagógiai kultúra, iskolaszerkezeti sajátosságok stb.). Hazai és nemzetközi mérések alapján egyértelmü, hogy az elkülönülés alapja a társadalmi csoporthoz tartozás. Könnyen belátható, hogy az erős érdekérvényesítő képességgel rendelkező társadalmi csoportokhoz tartozó szülők szelektív iskolaválasztási döntéseinek és a magasabb presztízsü iskolák szelekciós iskolapolitikájának törvényszerü és párhuzamos következménye, hogy a ki nem válogatott gyermekek (jellemzően alacsony szociális státuszú, hátrányos és halmozottan hátrányos helyzetü és/vagy roma tanulók) beszorulnak a gyenge, rosszul felszerelt, alacsony hozzáadott értékü iskolákba.

A magyar iskolarendszerben évtizedeken keresztül kialakuló egyenlőtlenségek két fó oka az iskolák hátránykompenzációs képességének kóros gyengesége és a nemzetközi összehasonlításban rendkívül erős szelekció, a tanulók családi hátterüknek megfelelö intézmények közötti elkülönítése. A PISA mérések által alkalmazott, a hátránykompenzációs képesség mérését szolgáló mutató a tanulók eltérő családi háttere által okozott pontszámokban kifejezhető teljesítmény különbség. Mint az a 11. táblázat adatain jól látszik, ez a hatás nem önmagában és minden iskolában egyforma mértékben érvényesül, azt lényegében az iskolák közötti szelekció erősíti fel.

11. táblázat. A családi háttér és a szelekció teljesitménykülönbségekre gyakorolt hatása Magyarországon (Forrás: OECD, 2013, 2016)

\begin{tabular}{lccc}
\hline & $\begin{array}{c}\text { A családi hát- } \\
\text { tér egy egy- } \\
\text { ségnyi eltérése } \\
\text { által okozott } \\
\text { eredmény- } \\
\text { különbség }\end{array}$ & $\begin{array}{c}\text { Várható eredménykü- } \\
\text { lönbség, ha két tanuló } \\
\text { iskolájának státusza } \\
\text { azonos, családjaik státu- } \\
\text { sza között pedig egy egy- } \\
\text { ségnyi különbség van }\end{array}$ & $\begin{array}{c}\text { Várható eredménykü- } \\
\text { lönbség, ha két tanuló } \\
\text { családjának státusza } \\
\text { azonos, iskoláik státusza } \\
\text { között pedig egy egység- } \\
\text { nyi különbség van }\end{array}$ \\
\hline Matematika 2012 & 47 pont & 3 pont & 98 pont \\
\hline $\begin{array}{l}\text { Természet- } \\
\text { tudomány } 2015\end{array}$ & 47 pont & 6 pont & 96 pont \\
\hline
\end{tabular}


Mindennek megfelelően a kompetenciamérés 8 . évfolyamos adatai alapján azt vizsgáltuk, hogy 2010 és 2016 között a magániskolai hálózat térnyerése hogyan hatott a szelekció mértékének alakulására. Ehhez természetesen az elemzést azokra a településekre szükítettük, amelyek legalább két vagy több iskolával („feladatellátási hellyel”) rendelkeztek.

A nem állami fenntartók belépésének hatásvizsgálata érdekében a többiskolás településekből három csoportot képeztünk. (1) A Báziscsoportba azok a települések kerültek, ahol 2010-ben csak közösségi (önkormányzati) fenntartású iskola volt, 2016-ban pedig már jelen volt nem állami fenntartó is. Az ebbe a körbe került 30 településen mérhető a privatizáció hatása. (2) Az első kontrollcsoportunkba, a Vegyes csoportba azok a települések kerültek, ahol 2010-ben és 2016-ban egyaránt vegyes (közösségi, egyházi és egyéb magán) tulajdonosi kör volt jelen (116 település). (3) A második kontrolcsoportot, az Állami csoportot olyan településekböl képeztük, melyek 2010-ben csak önkormányzati, 2016-ban csak állami iskolával rendelkeztek (55 település).

A Báziscsoportban 2016-ra minden településen megjelent valamelyik felekezet, az intézmények egyharmada került egyházi tulajdonba. A települések e csoportjában nincs nem egyházi magániskola. A Vegyes csoportban csökkent az állami és nem egyházi magánszektor jelenléte, az egyházi iskolák aránya azonban 5 százalékkal növekedett, 116 településből 110-ben van egyházi iskola. 2016-ban az állami iskolák száma 10 százalékkal csökkent, az egyházi iskoláké 23 százalékkal nőtt, a nem egyházi magániskolák 13 százalékkal vannak kevesebben (14. ábra).

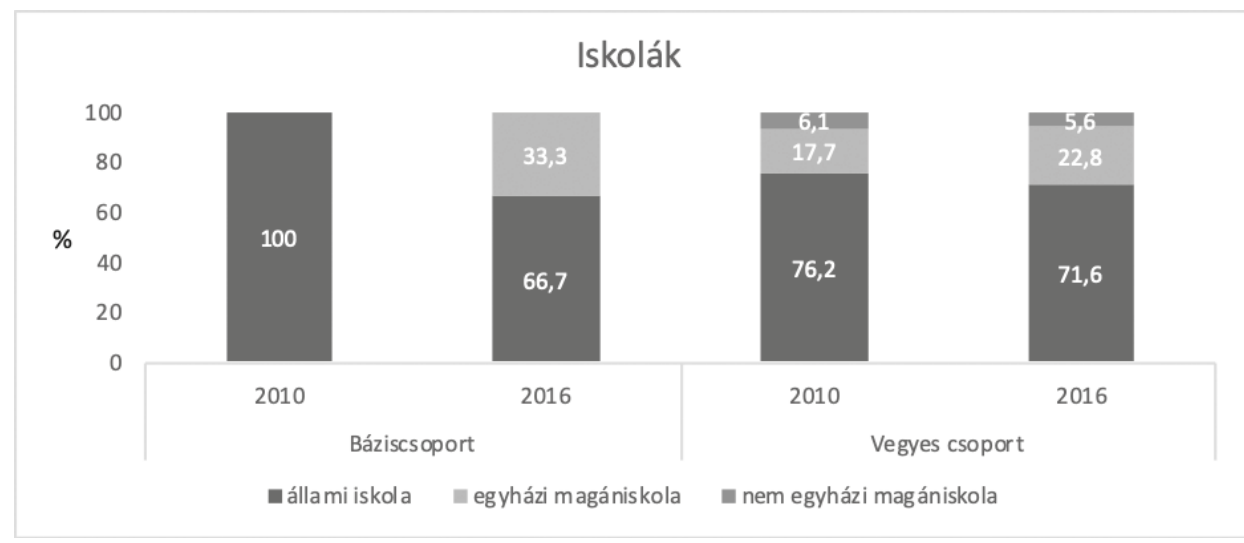

14. ábra. Az egyes szektorok iskolai részesedésének aránya (\%) a vizsgált csoportokban 2010-ben és 2016-ban (Forrás: OKM 8. évfolyam)

\section{A privatizáció hatása a településeken belüli szelekció mértékére}

A privatizáció és a státuszalapú szelekció kapcsolatát az Országos Kompetenciamérés családiháttér-index (CSHI) mutatójának segítségével vizsgáltuk. Az egyes szektorok tanulóinak CSHI-átlagai a 15. ábrán láthatók. A Báziscsoportban 2010-ben az önkormányzati iskolák CSHI-átlaga majdnem egytizeddel alacsonyabb volt, mint az országos átlag. Ez nem véletlen: a 2011-2013 közötti időszakban lezajlott fenntartóváltási hullámban jellemzően a hátrányos helyzetü területek önkormányzatai választották ezt a megoldást financiális okokból (Tomasz, 2017). Emiatt kerültek be a hatásvizsgálati csoportba nagyobb számban éppen azok a települések, amelyek a nem állami fenntartókat (az egyházakat) behívták. 2016-ban e településeken már a fenntartói szektorok mentén rendeződik a tanulók eloszlása: az egyházi szektor tanulói CSHI-átlaga 0,2-del magasabb, mint az állami tanulóké. 
A Vegyes csoportban az egyes szektoroknak már a 2010-es CSHI-átlagai is több tizeddel magasabbak voltak, mint az országos átlag. Ennek magyarázatát abban találjuk, hogy 2011 előtt zömében ott müködtek egyházi iskolák, ahol ez világnézetileg volt indokolt. Egy 2012-es vizsgálat azt találta, hogy a vallásos nevelésben részesülő fiatalok nagy aránya az ország középső és nyugati - tehetősebb - részére jellemző, tehát az érintett települések teljes lakosságának szocio-ökonómiai mutatói értelemszerủen magasabbak, mint a hátrányos helyzetü térségek településein élőké (Rosta, 2013).

A15. ábráról leolvasható az állami és nem állami szektorok tanulói köre közötti, társadalmi státusz szerinti markáns különbség mind a két évben. A legmagasabb értékei a nem egyházi magánszektornak vannak, az államihoz képest a különbség itt 0,3-nél nagyobb mind a két évben, az egyházi szektor átlagai pedig több mint 0,2-del magasabbak.

Az Állami csoport településeinek átlaga 2010-ben az országos átlagnál alig, csupán 0,02-dal alacsonyabb, 2016-ban megegyezik az országos átlaggal. A vizsgált időszakban azokon a településeken, ahol az állami fenntartó mellett nem jelentek meg sem egyházi, sem nem egyházi magániskolák, a CSHI-átlag csupán elhanyagolható mértékben változott.

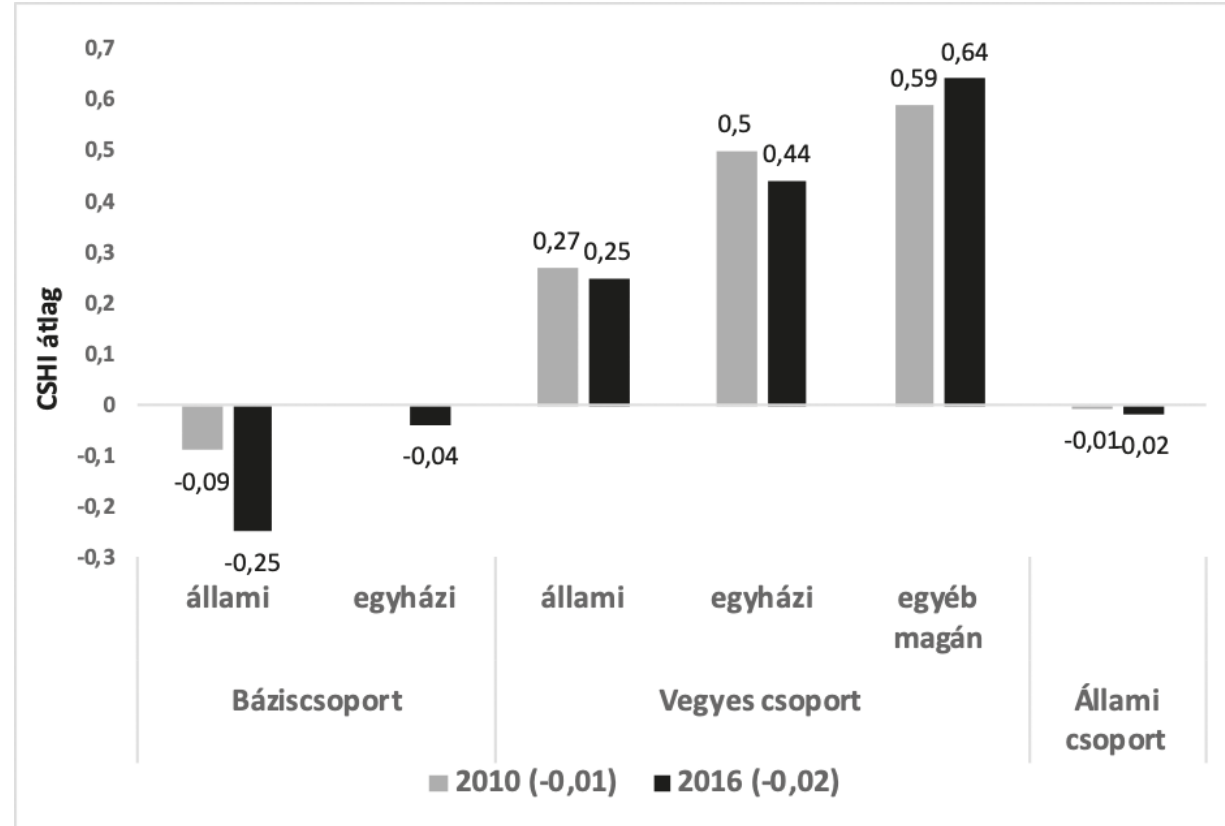

15. ábra. A Bázis, a Vegyes és az Állami csoport fenntartói szektorainak tanulói CSHI-átlaga 2010-ben és 2016-ban (az országos átlagok az évszámok mellett, forrás: OKM 8. évfolyam)

Mint korábban már jeleztük, az egyházi intézmények tanulóinak CSHI-átlaga markánsan magasabb, mint az állami iskolában tanulóké (Ercse, 2018, 2019). A privatizáció hatásvizsgálata szempontjából a következőket tudjuk leolvasni az ábráról. Az egyes szektorok tanulói CSHI-átlag szerinti vizsgálatából kiderül - különösen a Bázis- és az Állami csoport összevetése alapján -, hogy a privatizációval belépő egyházi szektor hatására a tanulók eloszlása családi hátterük alapján polarizálódik; az egyházi iskolák egyértelmüen az elit gyermekeire szelektálnak. A Vegyes csoport mutatói alapján pedig elmondható, hogy a nem állami (egyházi és nem egyházi magán) fenntartók jelenléte általában is nagymértékü szelekciót generál. 
Ahhoz, hogy a települési szintű szelekció mértékéről pontos fogalmat alkothassunk, az iskolai CSHI-átlagok települési szórásainak átlagát használtuk fel (16. ábra). A nagy szórás magas szelekciót jelez. Figyelembe véve, hogy az országos tanulói CSHI-k szórása nagyjából 1, jól látható, hogy mindhárom csoportban már 2010-ben is magas volt a szelekció. A legmagasabb a Vegyes csoportban volt, kevés híján félszórásnyi. 2016-ra a két kontrollcsoportban tulajdonképpen nem változott a szelekció mértéke, a Báziscsoportban azonban - az egyházi iskolák megjelenésével - 30 százalékkal megnőtt.

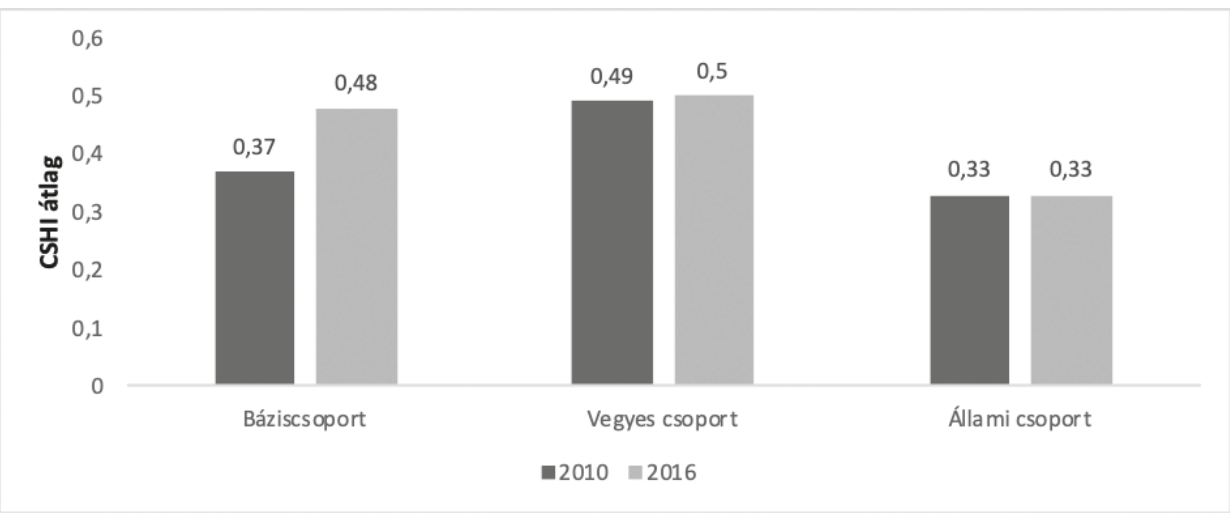

16. ábra. A vizsgált csoportok települései iskoláinak CSHI-átlagaiból számitható települési szórások átlaga, 2010-2016 (Forrás: OKM 8. évfolyam)

\section{A privatizáció hatása a települések közötti szelekció mértékére}

A települések közötti szelekció növekedését generáló folyamatot Zolnay János (2016) ingázási játszmának nevezi. A szabad iskolaválasztás lehetőségével élve a (relatív) elit egy része nem a körzeti iskolát választja, hanem egy számára megfelelö társadalmi összetételü iskolát (Hricsovinyi és Józsa 2018). A jelenség vizsgálatához az OKM alapján Bejáró-ként azonosítottuk azokat a tanulókat, akik lakóhelyének települése nem egyezik meg az iskola címének településével. ${ }^{6}$ A Vegyes kontroll csoportban (18. ábra) már 2010-ben is szembetünő volt, hogy a nem állami szektorokban a bejáró tanulók aránya az államihoz képest több mint kétszeres. 2016-ra a nem egyházi magánszektorban 8 százalékponttal nőtt meg az arányuk, ami érthető, hiszen az iskoláik száma csökkent, a szolgáltatásaik iránti igény viszont valószínűleg nem. Az egyházi szektorban a bejárók aránya 0,2 százalékponttal csökkent, ami szintén érthető, mivel az elérhető egyházi iskolák száma jelentősen megnőtt. A Báziscsoportban (17. ábra) nagyon látványos, ahogy a 2016-ra megjelenő egyházi szektorban a bejárók aránya az állami iskolákhoz képest kétszeres.

6 Ilyen módon a településen belüli iskolakörzetek közötti mozgást nem tudjuk figyelni, de a nagyobb városokban ilyen esetekben inkább jellemző a lakcímváltás (ismerőshöz vagy rokonhoz) a bekerülés érdekében (ld. iskolák felvételi kötelezettsége a körzetböl). 
Ercse Kriszta - Radó Péter: A magyar közoktatásban zajló privatizáció és annak hatásai

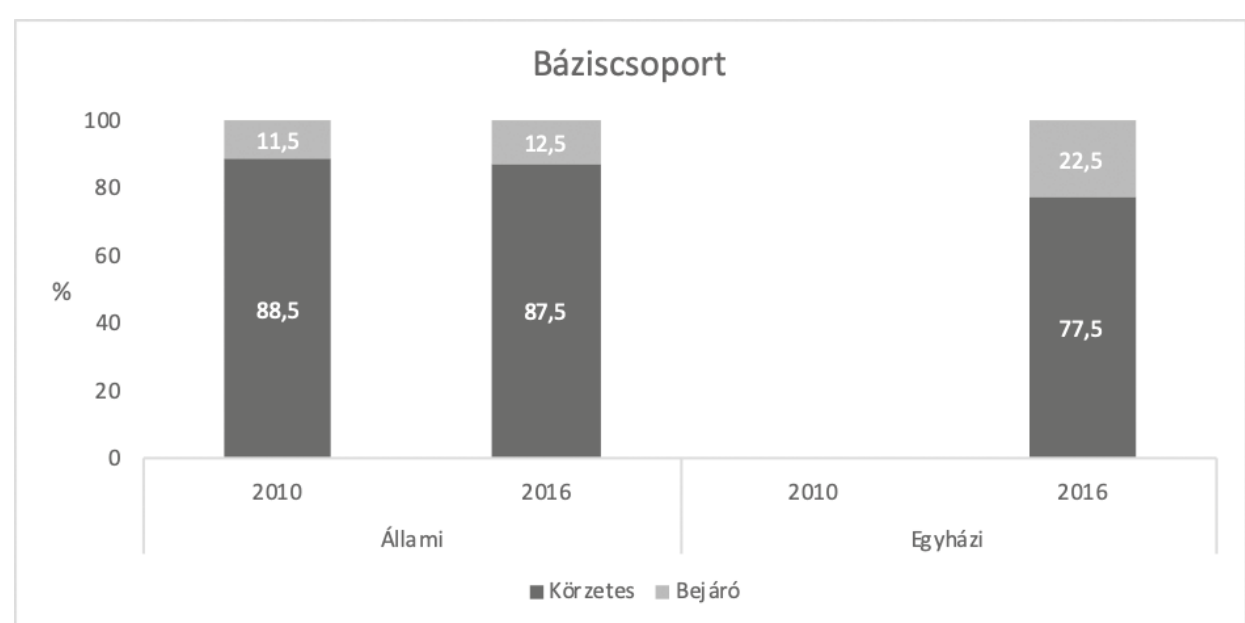

17. ábra. A körzetes és bejáró tanulók aránya a Báziscsoport fenntartói szektorai szerint (\%, 2010-2016, forrás: OKM 8. évfolyam)

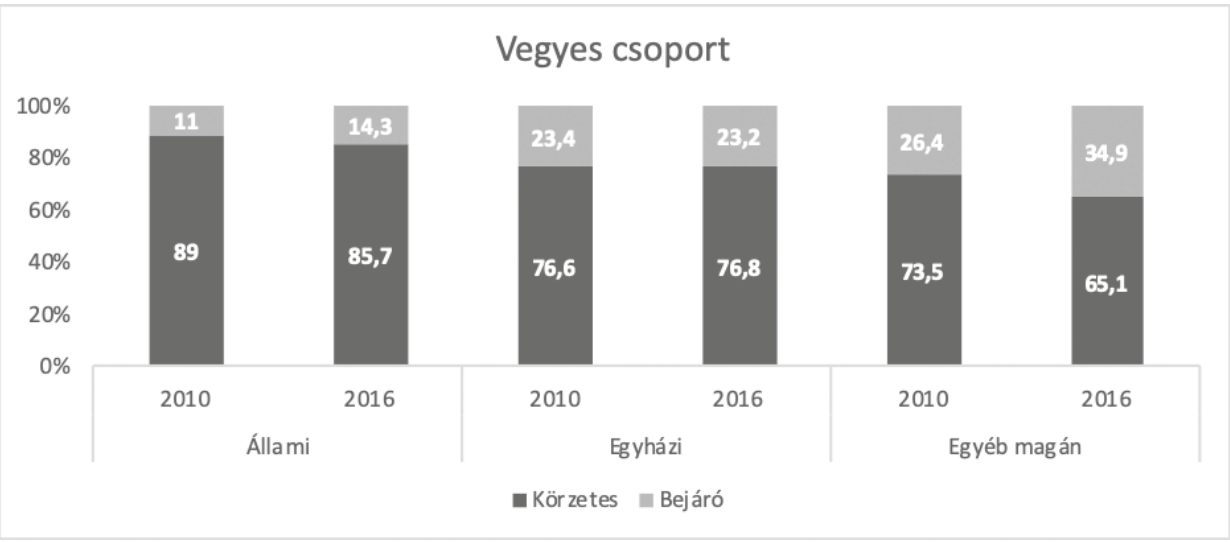

18. ábra. A körzetes és bejáró tanulók aránya a Vegyes csoport fenntartói szektorai szerint (\%) (2010-2016, forrás: OKM 8. évfolyam)

A szelekció erősödésének folyamata akkor lesz igazán érthető, ha a körzetesek-bejárók CSHI-átlagait megnézzük szektoronként (19. és 20. ábrák). Mind a két településcsoportról megállapítható, hogy a bejáró tanulók CSHI-átlaga jelentős mértékben magasabb, mint a körzetes tanulóké. A Vegyes csoport esetében itt is jól látszik, hogy a szektorok tanulói körének CSHI-átlaga mind a körzetes tanulók, mind a bejáró tanulók esetében markánsan eltér. A nem egyházi magánszektor CSHI-átlag növekedése alapján elmondható, hogy jellemzően a legmagasabb státuszú családok keresik ezt a szolgáltatást. Az egyházi szektorban látható CSHI-csökkenések pedig egyrészt mutatják, hogy a fenntartóváltásokat követően a kevésbé tehetős területekről bekerülő tanulók lehúzzák az átlagot, másrészt jelzik, hogy a szegényebb területeken is a relatív elit keresi az egyházi iskolákat. Ez utóbbi állítást a Báziscsoport ábrája támasztja alá: a szektorok 2016-os értékei mutatják, hogy az egyházi iskolák „elszívják” a relatíve kedvezőbb hátterü gyermekeket. 


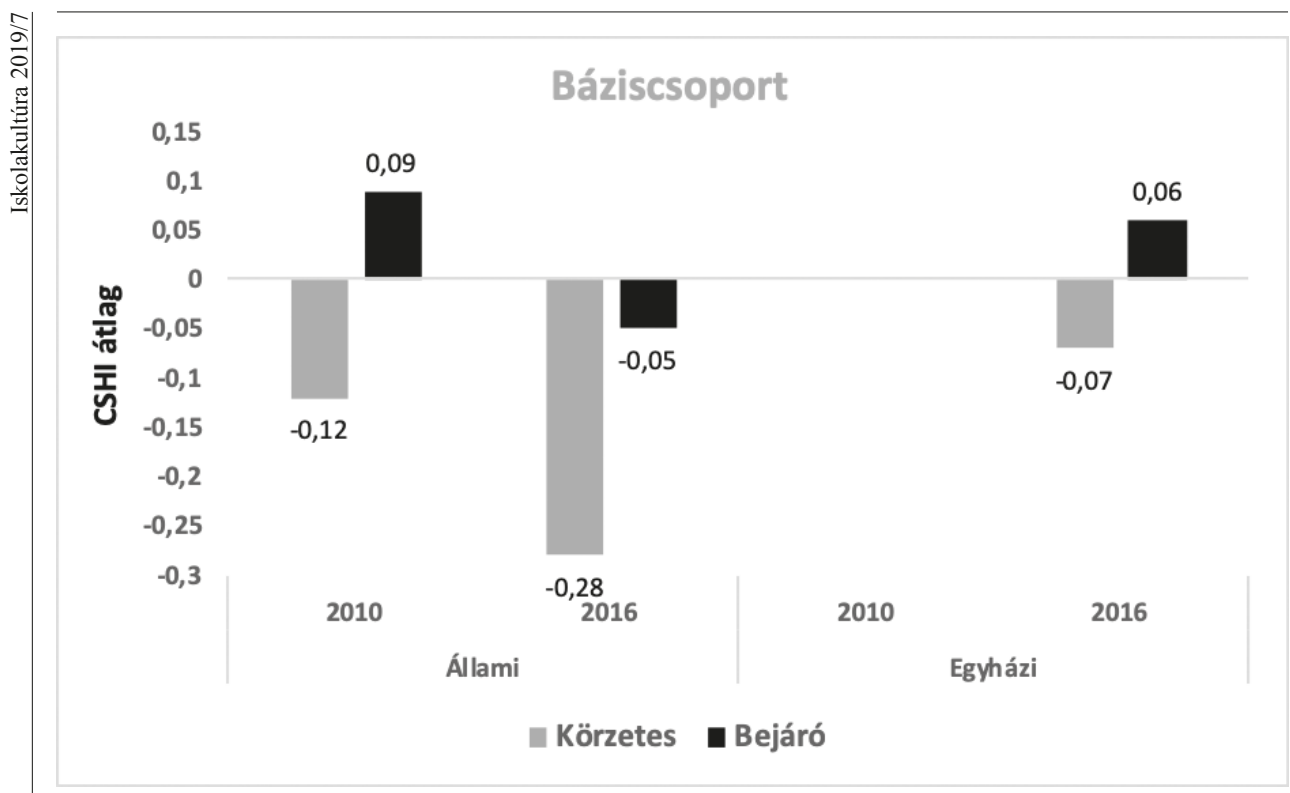

19. ábra. A körzetes és bejáró tanulók CSHI-átlagai a Báziscsoport fenntartói szektorai szerint (2010-2016, forrás: OKM 8. évfolyam)

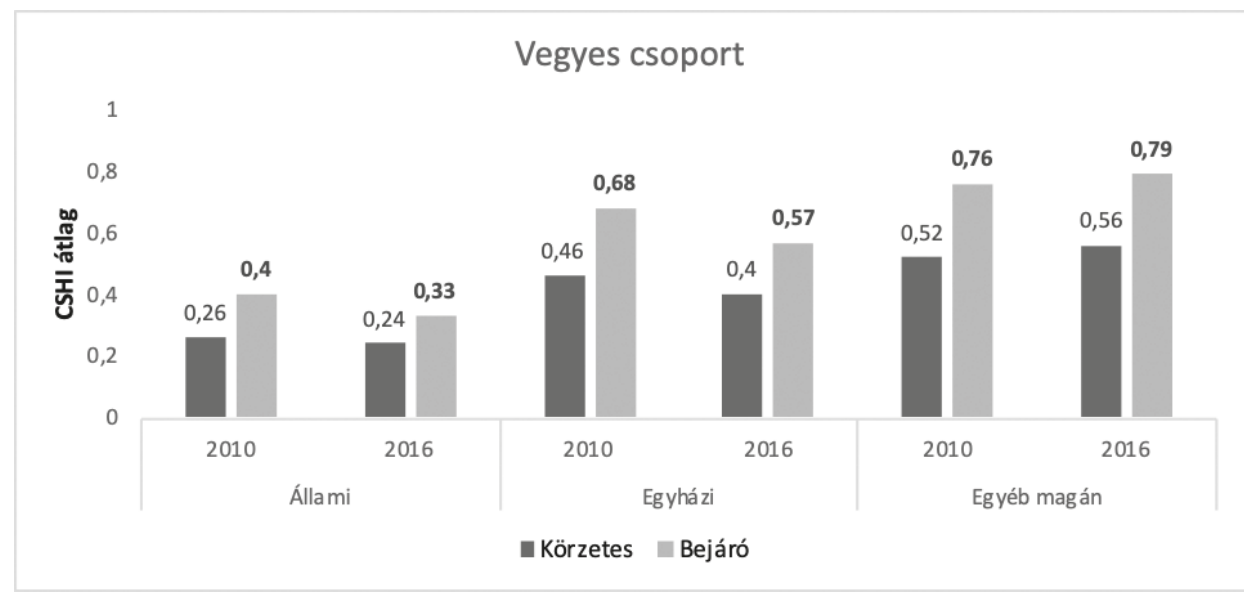

20. ábra. A körzetes és bejáró tanulók CSHI-átlagai a Vegyes csoport fenntartói szektorai szerint (2010-2016, forrás: OKM 8. évfolyam)

A szelekció további rétegeinek feltárásához szóráselemzést végeztünk. Azt vizsgáltuk, hogy az iskolák közötti különbségek hogyan változtak (szelekció mértékének változása, 21. ábra), illetve a településen belüli és települések közötti különbségek mértékéröl is képet kaptunk. A vizsgált egységek (faktor) a települések voltak, a szóráselemzés egyedei az iskolák, a vizsgált változó az iskolák CSHI-átlaga (12. táblázat). 
Ercse Kriszta - Radó Péter: A magyar közoktatásban zajló privatizáció és annak hatásai

12. táblázat. A szóráselemzéssel számított eltérés-négyzetösszegek a vizsgált csoportokhoz tartozó településeken 2010-ben és 2016-ban (Forrás: OKM)

\begin{tabular}{llccc}
\hline \multirow{2}{2010}{} & & Báziscsoport & Vegyes csoport & Állami csoport \\
\cline { 2 - 5 } & Településeken belül & 23,32 & 413,71 & 17,30 \\
\cline { 2 - 5 } & Települések között & 13,06 & 122,64 & 16,64 \\
\cline { 2 - 5 } & Teljes & 36,38 & 536,35 & 33,93 \\
\hline \multirow{2}{*}{016} & Településeken belül & 29,29 & 357,45 & 15,53 \\
\cline { 2 - 5 } & Települések között & 23,92 & 122,68 & 22,94 \\
\cline { 2 - 5 } & Teljes & 53,20 & 480,13 & 38,47 \\
\hline
\end{tabular}

A szelekció a 2010-es állapothoz képest a Báziscsoportban változott a leglátványosabban: majdnem 50 százalékkal nőtt meg az egyházi fenntartók belépését követően. Az Állami kontrollcsoportban is nőtt a szelekció mértéke 13 százalékponttal, a Vegyes csoport esetében 10 százalékpontos csökkenés látható. Erre a magyarázat nem egy kedvező folyamat, hanem az, hogy ebben a csoportban 2016-ra ötvennyolccal kevesebb iskola volt. Azokon a településeken, ahol 2010-ben voltak nem állami iskolák, a szelekció mértéke jelentősen nem változott, már eleve nagyon magasnak volt mondható.

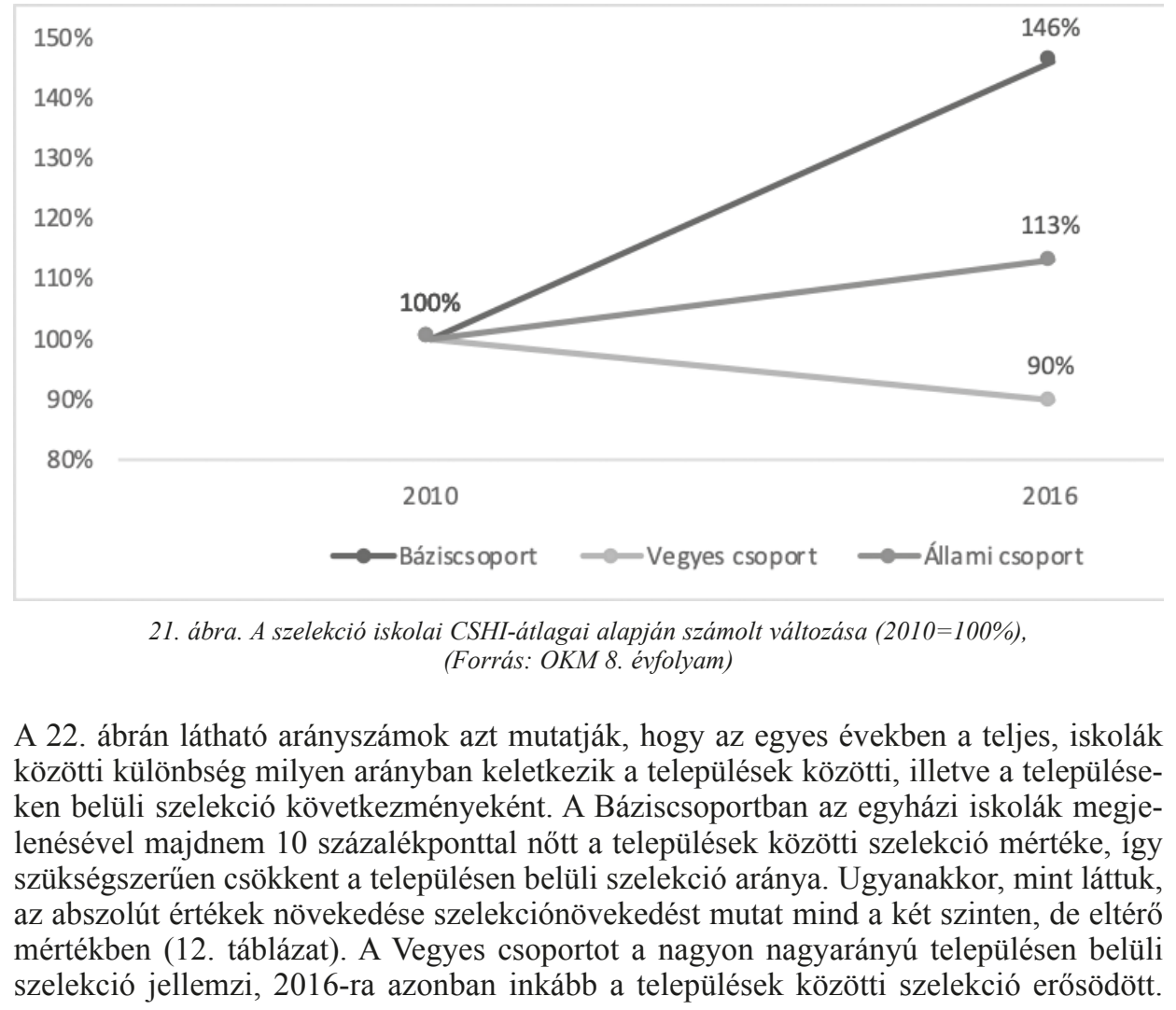


Az Állami csoportban is jelentősen nőtt a települések közötti szelekció. A körzetes és bejáró tanulói csoportok arányainak, illetve a CSHI-átlagok vizsgálata megerősíti, hogy a településen belüli szelekció során a nem állami fenntartókhoz kerülnek a magasabb státuszú tanulók. Ugyanakkor magyarázatot kapunk a települések közötti szelekció mechanizmusára is: a relatíve magas státuszú tanulók más település magas presztízsú iskoláit választják. A privatizációs hatás ebben az esetben is teljesen egyértelmü: a nem állami fenntartók bejáró tanulóinak nem csupán a CSHI-átlagaik magasabbak jelentősen, hanem az arányuk is kétszer, háromszor akkora, mint az állami fenntartók esetében. Ilyen módon a szociálisháttér-alapú különbség még jobban növekszik azok között a települések között, ahol van, illetve ahol nincs a középosztályi családok számára vonzó iskola.

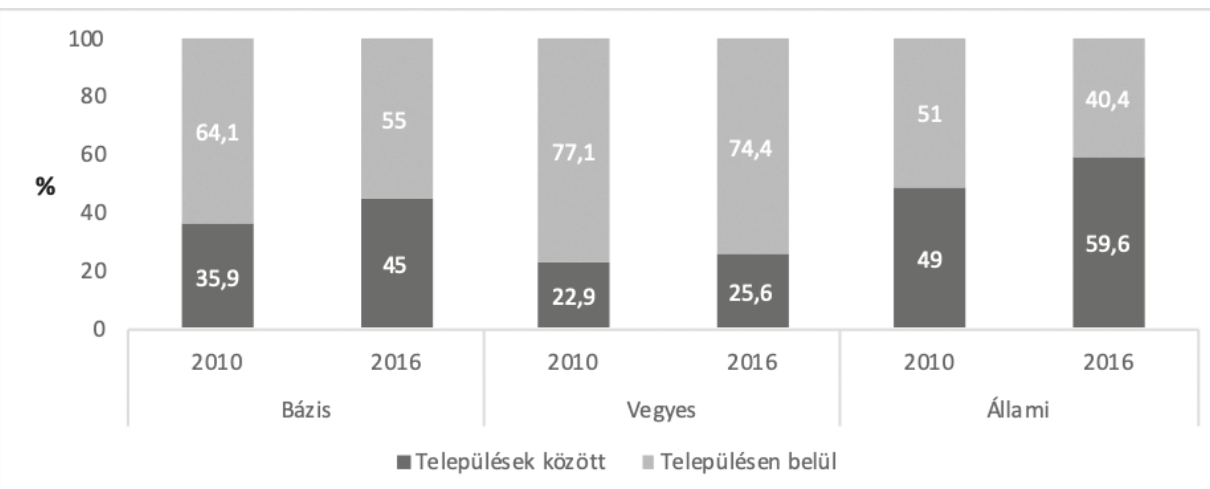

22. ábra. A településeken belüli és a települések közötti szelekciót jellemző arányok (\%, 2010-2016, forrás: OKM 8. évfolyam)

Összességében a CSHI mutató segítségével vizsgált szelekciós folyamatok és a privatizáció kapcsolatáról megállapítható, hogy a belépő nem állami fenntartók növelték a települési és települések közötti szelekciót. Az arányok alakulása alapján ebben különösen nagy szerepet játszott az egyházi iskolahálózat expanziója. A két nem állami iskolahálózat közül az egyházi fenntartók 50 százalékos növekedéséről beszélhetünk, 2016-ra a minimum kétiskolás települések kétharmadában vannak jelen, és az iskolák egyötöde tartozik hozzájuk. A nem egyházi magánszektor esetében azonban 20 százalékos térvesztésről beszélhetünk: a települések 13 százalékában vannak jelen, s az iskolák 4,5 százaléka nem egyházi magánintézmény. Ebből következően kimondható, hogy az egyházi szektor expanziója és a szelekció növekedése között egyértelmü kapcsolat van.

\section{A tulajdonosi szerkezet változása és a roma tanulók szegregációja}

A roma tanulók etnikai alapú elkülönítése Magyarországon jellemzően nem közvetlen módon történik, az etnikai szeparáció erösödése mögött lényegében ugyanazok a szelektív iskolaválasztáson és bizonyos iskolák szelektív beiskolázási gyakorlatán alapuló mechanizmusok állnak, melyekről az eddigiekben szó volt. A roma tanulókat sújtó szegregáció tehát nagyrészt a közoktatásban egyre erőteljesebben érvényesülő szelekció, a roma tanulókkal összefüggésben a white flightnak nevezett jelenség egyenes következménye (Radó, 2018). 
A roma szegregáció mértékét két oktatásszociológiai kategória jelzi: a gettósodó iskolában a roma tanulók aránya 30 százalék és 50 százalék között van, a gettóiskolában 50 százalék felett. A roma tanulók elkülönítése a magyar közoktatásban már 2010 előtt is rendkívül erős volt. A gettóiskolák száma és aránya 2010 óta szívósan tovább növekedett (13. táblázat). Noha több évtizedes távlatban az etnikai szeparációban szerepet játszik a roma tanulók közoktatáson belüli arányának növekedése és a roma lakosság területi koncentrációja is, a gettóiskolák számának 2010 utáni erősödésében a roma tanulók számának stagnálása miatt nem ez játszott közre.

13. táblázat. A roma gettóiskolák számának és arányának változása Magyarországon (általános iskolai oktatás, 2010-2016, forrás: OKM, Nahalka István számításai)

\begin{tabular}{lccccccc}
\hline \multicolumn{1}{c}{ Indikátor } & $\mathbf{2 0 1 0}$ & $\mathbf{2 0 1 1}$ & $\mathbf{2 0 1 2}$ & $\mathbf{2 0 1 3}$ & $\mathbf{2 0 1 4}$ & $\mathbf{2 0 1 5}$ & $\mathbf{2 0 1 6}$ \\
\hline Gettóiskolák száma & 304 & 299 & 314 & 325 & 337 & 347 & 369 \\
\hline Gettóiskolák aránya (\%) & 12 & 12 & 12,8 & 13,3 & 13,6 & 13,9 & 14,9 \\
\hline
\end{tabular}

Az Országos Kompetenciamérés iskolai romaarány mutatójának segítségével az etnikai alapú szelekció alakulását a szelekció elemzése érdekében létrehozott három többiskolás településcsoportban is megvizsgáltuk. A gettósodó, a gettóiskolák, valamint az érintett települések számának és arányának változását összefoglaló 23. ábra adatain jól látszik, hogy 2010-ben a vizsgált csoportok közül a heterogén fenntartói körrel rendelkező Vegyes csoportban volt a legmagasabb mind a gettósodó, mind a gettóiskolákkal rendelkező települések aránya. A Báziscsoporttal összehasonlítva a Vegyes csoportban a gettósodó iskolák településeinek aránya 15 százalékkal volt magasabb, a gettóiskolák településeinek esetében pedig a különbség majdnem másfélszeres volt. Az Állami csoporttal összehasonlítva a Vegyes csoportban több mint másféleszeres volt azoknak a településeknek az aránya, ahol müködött gettósodó iskola $(26,7 \%)$ vagy gettóiskola $(24 \%)$.

2016-ra a Vegyes csoportban 1,7 százalékponttal csökkent azon települések aránya, ahol müködött gettósodó iskola, így a települések egynegyede volt érintett. Mindeközben azonban e csoportban 28,4 százalékra nőtt azon települések aránya, ahol gettóiskola müködött, tehát a gettósodó iskolák egy részében többségbe kerültek a roma tanulók. Az Állami csoportban 16,4 százalékról 20 százalékra nőtt a gettósodó iskolák településeinek aránya, a gettóiskolák településeinek aránya kisebb mértékben nőtt.

A roma szelekció mértéke tehát mind a két kontrollcsoportban nőtt, a vegyes fenntartói kör csoportjában ezen arányok eleve

\section{A roma szegregáció mértékét} két oktatásszociológiai kategória jelzi: a gettósodó iskolában a roma tanulók aránya 30 százalék és 50 százalék között van, a gettóiskolában 50 százalék felett. A roma tanulók elkülönitése a magyar közoktatásban már 2010 elótt is rendkiviül erôs volt. A gettóiskolák száma és aránya 2010 óta szívósan tovább növekedett. Noha több évtizedes távlatban az etnikai szeparációban szerepet játszik a roma tanulók közoktatáson belüli arányának növekedése és a roma lakosság területi koncentrációja is, a gettóiskolák számának 2010 utáni erôsödésében a roma tanulók számának stagnálása miatt nem ez játszott közre. 
magasabbak voltak. A nem állami fenntartók belépésének hatása (a privatizációs hatás) az etnikai alapú elkülönítésre a Báziscsoportban igen látványos volt: a gettósodó iskolák településeinek aránya 23,3 százalékról 33,3 százalékra nőtt, a gettóiskolák településeinek aránya pedig kevés híján megduplázódott: 16,6 százalékról 30 százalékra nőtt.

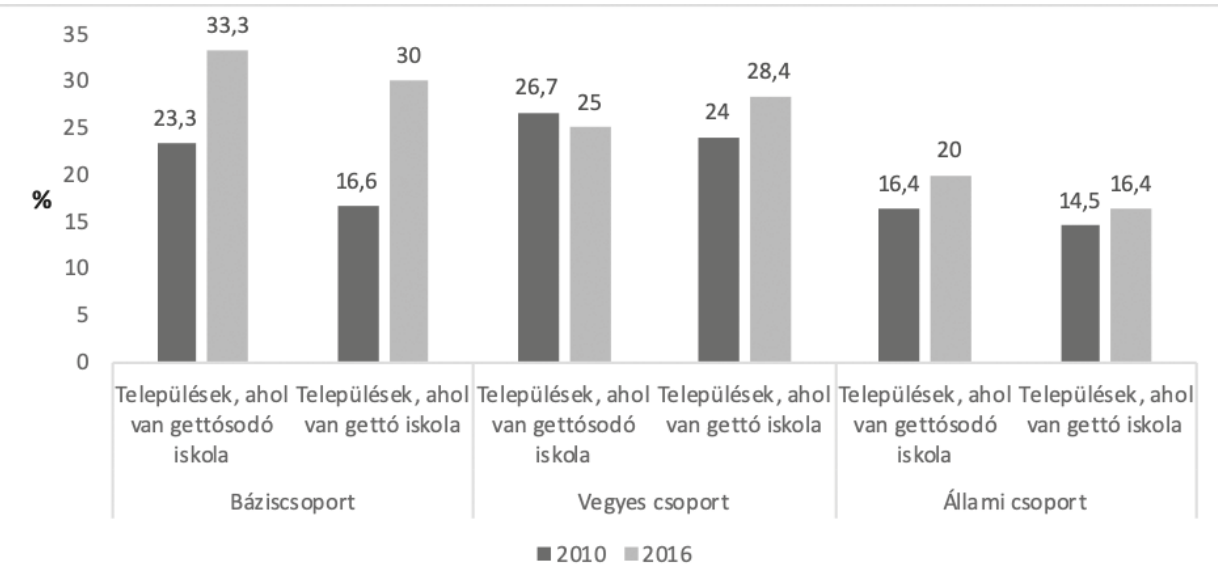

23. ábra. A gettósodó és gettóiskolák településeinek aránya (\%) a három vizsgált csoportban 2010-ben és 2016-ban, (Forrás: OKM 8. évfolyam)

A szegregáló iskolák tulajdonosi körének vizsgálata az erről szóló korábbi elemzéshez (Ercse, 2019) hasonló eredményt hozott: a gettósodó és gettóiskolák tulajdonosai az esetek döntő többségében ( 80 százalék felett) mind a két vizsgált évben az önkormányzatok, illetve az állam voltak. A roma tanulók felülreprezentáltsága nem a közvetlenül érintettek (iskola, szülök, diákok) döntésének eredménye, hanem a települési iskolahálózat többi szereplőjének szelekciós, szeparációs politikájának a következménye volt (Ercse 2018; Lannert és mtsai, 2018; Zolnay, 2016, 2018). A szelekciós folyamat során, amikor bizonyos iskolák leválogatják a magas státuszú családok gyermekeit, a szegény és/vagy roma tanulók az ún. „gyüjtőiskolákban” koncentrálódnak, melyek jellemzően a helyi iskolahálózat hierarchiájának alján találhatók. ${ }^{7}$ A gettósodó és gettóiskolák túlnyomó részben alacsony presztízsü állami iskolák, illetve kisebb számban vannak olyan magán és felekezeti iskolák is, ahol mintegy krízisintervenciós jelleggel második esély, illetve hátránykompenzációs programot ${ }^{8}$ kínálnak a szelekció vesztesei számára.

A vizsgált településcsoportokban nőtt az egyházi fenntartású gettósodó, illetve gettóiskolák aránya, a nem egyházi magániskolai körben viszont mindkettő aránya csökkent. Ennek egyik oka, hogy az egyházi iskolahálózat terjeszkedése jórészt olyan régiókat érintett, ahol a lakosság jelentős hányada roma származású, így az iskolák tanulói

7 Az intézmény, illetve az iskolahasználók - szülők és diákok - érdekérvényesítési képessége nagyon alacsony; szegény, HH, HHH és roma családok, szemben a magas státuszú iskolaközösségekkel.

8 Például: Magániskolák: Burattino Iskola https://www.burattino.hu/, Magiszter Alapítványi Óvoda, Általános Iskola, Gimnázium, Szakgimnázium és Szakközépiskola Tiszavasvári Tagintézménye http://tiszavasvari. magiszteralapitvany.hu/

Egyházi iskolák: Nyitott Ajtó Baptista Általános Iskola, Óvoda, Szakképző Iskola, Középiskola és Kollégium http://baptistaiskola.hu/, Wesley János Óvoda, Általános Iskola, Szakiskola és Gimnázium http://metegyhaz. hu/budapest---wesley-janos-ovoda,-alt.-isk.,-szakisk.,-es-gimnazium.html 
összetétele a lakóhelyi elkülönülés mértékét tükrözi. ${ }^{9}$ Korábbi kutatások elemezték az egyházi iskolahálózat szegregált iskoláinak felekezeti fenntartói összetételét, valamint a helyi intézményhálózatok által kijelölt kontextust (Ercse, 2019). Az eredmények szerint az esetek 65 százalékában a településen a szegregált egyházi iskolák mellett müködik másik egyházi iskola is, melynek tanulói köre a családiháttér-indexek átlagai alapján a helyi elitből kerül ki. E települések 41 százalékában a két intézmény - a szegregált és a szelektáló - fenntartója ugyanaz a felekezet, a katolikus vagy református ${ }^{10}$ egyház.

Összefoglalva, a nem állami, többnyire egyházi fenntartók belépését követően a roma tanulók elkülönítése fokozódott. A jelentős mértékü növekedés és az egyházi fenntartók kapcsolatát különösen jól mutatják a Báziscsoport adatai, melyben az iskolai szegregációban érintett települések aránya megduplázódott. A szélsőségesen magas roma tanulói aránnyal rendelkező iskolák döntő többségben az állami fenntartóhoz tartoznak, tehát az egyházi iskolák szelektív beiskolázási gyakorlatának következtében a szelekció egyenes következményének tekinthető szegregáció ugrásszerüen megnőtt.

\section{Oktatáspolitikai dilemmák}

Mint az eddigiekből látható, a magánszektor növekedése az elmúlt évtizedben elérte azt a mértéket, ahol az már az egész közoktatási rendszer teljesítményére hatást gyakorol. Ez a hatás közpolitikai értelemben egyértelmüen negatív: a magániskolai hálózat bővülése egyértelmüen káros hatást gyakorolt a rendszer hatékonyságára, valamint erősítette a közoktatás szelektivitását, ezen belül a roma tanulók szegregációját. A magyar közoktatásban zajló minőségromlás, s ennek következtében az oktatási eredmények gyors romlása azonban nem a privatizáció, hanem az ,államosítás" módjának és egyéb negatív hatású oktatáspolitikai beavatkozásoknak a következménye. E tekintetben a magániskolák térnyerése bizonyos magasabb státuszú társadalmi csoportok esetében kármentő hatású volt, amennyiben lehetőséget

9 Például: Jászladány, 2 iskola - katolikus iskola: 40\%, állami iskola: 99\% romaarány.

10 Például: Makó, Karcag, Jászapáti, Pécs, Kazincbarcika

Mint az eddigiekból látható, a magánszektor növekedése az elmúlt évtizedben elérte azt a mértéket, ahol az már az egész közoktatási rendszer teljesítmé-

nyére hatást gyakorol. Ez a hatás közpolitikai értelemben egyértelmúen negatív: a magániskolai hálózat bôvïlése egyértelmúen káros hatást gyakorolt a rendszer hatékonyságára, valamint erôsitette a közoktatás szelektivitását, ezen belül a roma tanulók szegregációját. A magyar közoktatásban zajló minóségromlás, s ennek következtében az oktatási eredmények gyors romlása azonban nem a privatizáció, hanem az „államosítás" módjának és egyéb negatív hatású oktatáspo-

litikai beavatkozásoknak a következménye. E tekintetben a magániskolák térnyerése bizonyos magasabb státuszú társadalmi csoportok esetében kármentố hatású volt, amennyiben lehetóséget biztosított a romló minóséget nyújtó állami iskolák elkerülésére. Ez azonban az egyenlótlenségek erôsödése és a szelekció növekedése miatt a rendszer általános teljesítményének romlásával járt együtt. 
biztosított a romló minőséget nyújtó állami iskolák elkerülésére. Ez azonban az egyenlötlenségek erösödése és a szelekció növekedése miatt a rendszer általános teljesítményének romlásával járt együtt.

2010 óta az iskolarendszer tulajdonosi szerkezetével kapcsolatos oktatáspolitikai gyakorlatot kettős magatartás jellemzi. Egyfelöl megfigyelhető a közösségi tulajdonban lévő iskolahálózat részleges privatizációja, az egyházi tulajdonban lévő iskolahálózat bővülésének erőteljes és aktív kormányzati támogatása. Másfelől a nagyobb anyagi erővel rendelkező családok igényeinek kiszolgálását nyújtó nem egyházi magániskolák újabban elindult bővülésével kapcsolatban a kormányzat alapvetően semleges magatartást tanúsít. E kétfajta magatartás együttesen egy jól dokumentálható módon károkat okozó oktatáspolitikai gyakorlat, amelyet tehát felül kell vizsgálni. E felülvizsgálat módja azonban nyitott kérdések sokaságát veti fel; az e politika által generált strukturális változások igen rövid idő alatt alapvetően változtatták meg azt a kontextust, amelyen belül a közoktatás minőségi, eredményességi, hatékonysági és méltányossági problémáinak megoldását szolgáló oktatáspolitikai alternatívák mérlegelhetők, ezért a 2010 előtti oktatáspolitikai gyakorlathoz és annak eszközrendszeréhez már nincs visszatérés.

Az eddigiekben elemzett adatok alapján nem kétséges, hogy az iskolák túl nagy száma által okozott hatékonyságromlás, a növekvő szelekció, a roma tanulók növekvő szegregációja és a közoktatás romló teljesítménye egymástól nem elválasztható problémák. Közpolitikai szempontból e problémahalmaz kulcseleme a szelektív iskolaválasztási döntések elképesztően nagy mozgástere. Ez a mozgástér keresleti oldalon csupán a szülöi jogok korlátozásával lehetne szükíthető, tehát kínálati oldali állami beavatkozásra, az iskolahálózat jelentős szükítésére és ehhez alkalmazkodó szabályozási keretek megalkotására lenne szükség. A finanszírozásba épített ösztönzők ma már nem lennének elégségesek, ugyanis azok már nem lennének képesek felülírni a mostanra kialakult, a szelekciót erősítő helyi érdekeltségi viszonyokat. Központi állami beavatkozásra, az iskolahálózat központi „racionalizálására" lenne tehát szükség. Természetesen, mivel a minőség és eredményesség romlásának elsődleges oka az ,államosítás”, illetve annak bürokratikus centralizáción alapuló módja, az iskolahálózat racionalizálása önmagában nem orvosolná azt. Másfelől

Az iskolahálózat racionalizálásának kulcseleme az egyházi tulajdonban lévó iskolahálózat szerepéról szóló, minden érdekelt szerepló bevonásával megszületố oktatáspolitikai döntés. Az egyházi iskolák oly módon váltak a közoktatási szolgáltató rendszer kulcsszereplóivé, hogy az aktuálpolitikai szempontok érvényesitésével keletkezó preferenciális szabályok mellett rendelkeznek a speciális tanulói és szülói igények kielégitésére hivatott magániskolák nagyobb szakmai, gazdálkodási és intézményi lehetốségeivel is. Egy központi iskolahálózat-racionalizálási stratégia megalkotása elótt azt szükséges eldönteni, hogy a kialakult új helyzethez alkalmazkodva az egyházi iskolákat a közösségi közoktatási szolgáltatások részévé kivánjuk tenni, vagy a privatizációs folyamat felgyorsulása elótti idôszakban játszott szerepükhöz visszatérve továbbra is a vallásos nevelés iránti sajátos szülói igények kielégitését tartjuk fó feladatuknak. 
viszont az bármilyen oktatási reform előfeltétele, mely nélkül ma már a közoktatás minősége és eredményessége nem javítható és a kialakult oktatási egyenlőtlenségek nem mérsékelhetők. A jóval kevesebb és nagyobb létszámú iskola müködtetése mellett szól a közoktatási rendszerek fejlődésének iránya is: az adaptív készségek fejlesztésére orientált hatékony és aktív tanulás feltételezi, hogy az iskolák rendelkezzenek a gazdag tanulási környezet kialakításához szükséges intézményi szintủ kompetenciákkal (Radó, 2017). E kompetenciák elvárt gazdagodása azonban kis létszámú iskolákban egyre nehezebben valósulhat meg, tehát a nagyobb iskolaméret egyre inkább a minőség előfeltételévé válik.

Az iskolahálózat racionalizálásának kulcseleme az egyházi tulajdonban lévő iskolahálózat szerepéről szóló, minden érdekelt szereplő bevonásával megszülető oktatáspolitikai döntés. Az egyházi iskolák oly módon váltak a közoktatási szolgáltató rendszer kulcsszereplöivé, hogy az aktuálpolitikai szempontok érvényesítésével keletkező preferenciális szabályok mellett rendelkeznek a speciális tanulói és szülői igények kielégítésére hivatott magániskolák nagyobb szakmai, gazdálkodási és intézményi lehetőségeivel is. Egy központi iskolahálózat-racionalizálási stratégia megalkotása előtt azt szükséges eldönteni, hogy a kialakult új helyzethez alkalmazkodva az egyházi iskolákat a közösségi közoktatási szolgáltatások részévé kívánjuk tenni, vagy a privatizációs folyamat felgyorsulása előtti időszakban játszott szerepükhöz visszatérve továbbra is a vallásos nevelés iránti sajátos szülöi igények kielégítését tartjuk fö feladatuknak.

Az első oktatáspolitikai opció tehát az egyházi iskolák közösségi szolgáltató rendszerbe integrálása. Ennek a döntésnek rendkívül eröteljes hatása lenne az egyházi tulajdonban lévő iskolák szabályozására, irányítására, finanszírozására és minőségbiztosítására. Lássuk az integrációs stratégia néhány következményét! Elsősorban: fel kellene számolni az egyházi intézményekre vonatkozó összes preferenciális és kedvezményes szabályozási elemet. Így például az egyházi intézmények számára is általános szabályokon alapuló módon beiskolázási körzetet és eljárásokat kellene meghatározni. Megszünne az egyházi iskolák állami iskoláktól eltérő tartalmi szabályozása, s egységesíteni kellene a tankönyvkínálathoz való hozzáférés szabályait is. A más felekezethez tartozó, vagy nem hívő szülők jogainak védelmében az egyházi iskolákban meg kellene tiltani a kötelező hittanoktatást, s azt kizárólag önkéntességen alapuló tanterven kívüli szolgáltatásként lehetne megszervezni. Fel kellene számolni az állami és egyházi iskolák finanszírozásának módjában és mértékében kialakult különbségeket, amelynek nyilvánvaló elöfeltétele a finanszírozás normativitásának helyreállítása. Szükség lenne arra is, hogy az egyházi iskolák integrálódjanak az egységes területi oktatásirányítási rendszerbe, melynek részét képezné a közép és hosszú távú közoktatási kapacitástervezésben való részvételük is. Az egyházi és állami iskolák eltérő hatékonyságjellemzői miatt, valamint az erre vonatkozó bírósági ítéletek következtében a többségében állami tulajdonban lévő szegregáló iskolák bezárása miatt egy ebben az integrált rendszerben lebonyolított iskolahálózat-racionalizáció elkerülhetetlenül az egyházi iskolák arányának további növekedésével eredményezné. S végül: egységes állami minőségértékelési rendszert kellene létrehozni és müködtetni.

A második megfontolható opció a közösségi (önkormányzati vagy állami) tulajdonban lévő iskolahálózat dominanciájának helyreállítása, s az egyházi iskolák klasszikus magániskolai kínálatbővítő szerephez való visszatérése. E döntés azt jelentené, hogy az egyházi iskolák - más magániskolákhoz hasonlóan - továbbra is a közösségi intézményeknél nagyobb mozgásteret élveznének, ugyanakkor ennek súlyos következményei lennének az egyházi iskolahálózat méretére. Ebben az esetben ugyanis, mivel az állam nem zárhat be más tulajdonában lévő intézményeket, az elkerülhetetlen iskolahálózat-racionalizációt meg kellene előznie minden olyan egyházi iskola államosításának, amelyek a 2010-ben és az azt követő évben a könnyített feltételek alapján kerültek önkormányzati/ állami tulajdonból egyházi tulajdonba. 
A nem egyházi magániskolák most elindult térnyerése még nem érte el azt a mértéket, amely a közösségi alapszolgáltatások fontos szereplőjévé változtatná azokat. Ebben az intézményi körben a kulcskérdés a minőségbiztosítás. Amennyiben egységes minőségstandardok alapján müködő külső intézményértékelés lenne Magyarországon, tehát ha a közoktatási szolgáltatások az autógyártáshoz vagy az éttermi szolgáltatásokhoz hasonlóan minőségbiztosított közszolgáltatások lennének, akkor számos nemrég alakult nem egyházi magániskola nagy valószínüséggel kihullana a rostán. A minőségbiztosítás (modern tanfelügyelet) ráadásul jelentősen növelné az új iskolák alapításához szükséges források mennyiségét, ami korlátokat szabna a szektor további növekedése számára.

A közoktatás privatizációjának következményeivel való szembenézést erőteljesen megnehezíti, hogy az erről szóló diskurzusban keverednek a szük értelemben vett oktatási - a diákok tanulásával összefüggő - szempontok, valamint az oktatáson kívüli érdekeken alapuló narratívák. Ez utóbbiak közé tartoznak például az egyházak társadalmi, missziós céljaival, a kistelepülések „népességmegtartó” erejével, a magániskolák szabadságmegőrző küldetésével, vagy az állam társadalomszervező szerepével kapcsolatos megfontolások. Az eddigiekben elemzett oktatási problémák megoldása, az oktatáspolitikai dilemmák eldöntése azonban kizárólag szúken értelmezett oktatási megfontolások alapján lehetséges.

A közoktatás privatizációjának következményeivel való szembenézést erôteljesen megneheziti, hogy az erról szóló diskurzusban keverednek a szúk értelemben vett oktatási - a diákok tanulásával összefüggó - szempontok, valamint az oktatáson kívüli érdekeken alapuló narrativák. Ez utóbbiak közé tartoznak például az egyházak társadalmi, missziós céljaival, a kistelepülések „népességmegtartó" erejével, a magániskolák szabadságmegórzó küldetésével, vagy az állam társadalomszervezó szerepével kapcsolatos megfontolások. Az eddigiekben elemzett oktatási problémák megoldása, az oktatáspolitikai dilemmák eldöntése azonban kizárólag szúken értelmezett oktatási megfontolások alapján lehetséges.

\section{Irodalom}

Ercse Kriszta (2018). Az állam által ösztönzött, egyház-asszisztált szegregáció mechanizmusa. In Fejes József Balázs \& Szűcs Norbert (szerk.), Én vétkem. Helyzetkép az oktatási szegregációról. Szeged: Motiváció Oktatási Egyesület. 177-199.

Ercse Kriszta (2019). Az egyházi fenntartású iskolák és a szelekció, szegregáció kapcsolata. Iskolakultúra, 19.

Hermann Zoltán \& Varga Júlia (2016). Állami, önkormányzati, egyházi és alapítványi iskolák: részarányok, tanulói összetétel és tanulói teljesítmények. In Kolosi Tamás \& Tóth István György (szerk.), Társadalmi Riport 2016. Budapest: TÁRKI. 311-333.

Hricsovinyi Julianna \& Józsa Krisztián (2018). Iskolaválasztás és szelekció. In Fejes József Balázs
\& Szücs Norbert (szerk.), Én vétkem. Helyzetkép az oktatási szegregációról. Szeged: Motiváció Oktatási Egyesület. 129-146.

Lannert Judit, Németh Szilvia \& Szécsi Judit (2018). Szegregáló deszegregáció? In Fejes József Balázs és Szücs Norbert (szerk.), Én vétkem. Helyzetkép az oktatási szegregációról. Szeged: Motiváció Oktatási Egyesület. 285-300.

OECD (2013). PISA 2012 Results. Vol. I: What Students Know and Can Do: Student performance in mathemat$i c s$, reading and science. Paris: OECD Publishing.

OECD (2016). PISA 2015 Results. Vol. I: Excellence and Equity in Education. Paris: OECD Publishing. DOI: $10.1787 / 9789264266490$-en 
OECD (2018). Education at a Glance 2018: OECD Indicators. Paris: OECD Publishing. DOI: 10.1787/ eag-2018-en

Radó Péter (2016). PISA 2015: miért romlanak az eredményeink? Tani-tani Online, http://www.tani-tani.info/pisa_2015

Radó Péter (2017). Az iskola jövője. Budapest: Noran Libro.

Radó Péter (2018). A közoktatás szelektivitása mint a roma szegregáció általános kontextusa. In Fejes József Balázs és Szücs Norbert (szerk.), Én vétkem. Helyzetkép az oktatási szegregációról. Szeged: Motiváció Oktatási Egyesület. 31-55.

Rosta Gergely (2013). Hit és vallásgyakorlat. In Székely Levente (szerk.), Magyar Ifjúság 2012 - Tanulmánykötet. Budapest: Kutatópont. 316-330.
Scheerens, J., Glas, C. \& Thomas, S. M. (2003). Educational Evaluation, Assessment and Monitoring. A Systemic Approach. Lisse: Swets \& Zeitlinger Publishers. DOI: 10.4324/9780203971055

Tomasz Gábor (2017). Erősödő egyházi jelenlét az oktatásban. Educatio, 26(1), 94-112. DOI: 10.1556/2063.26.2017.1.9

Varga Júlia (2018, szerk.). A közoktatás indikátorrendszere, 2017. Budapest: MTA KRTK Közgazdaság-tudományi Intézet.

Zolnay János (2016). Kasztosodó közoktatás, kasztosodó társadalom. Esély, 28(6), 70-97.

Zolnay, J. (2018). Commuting to segregation. The role of pupils commuting in a Hungarian city: between school segregation and inequality. Review of Sociology, 28(4), 133-151.

\begin{abstract}
Absztrakt
A 2010-től napjainkig tartó időszakban a magyar közoktatás tulajdonosi szerkezetében két nagy horderejü változás történt: az önkormányzati iskolák ,államosítása”, központi kormányzati tulajdonba vétele, valamint a közösségi tulajdonban lévő iskolák jelentős részének a kormányzat által támogatott privatizációja, különböző egyházi felekezeteknek való átadása. A tanulmány áttekintést nyújt a tulajdonosi szerkezet átalakulásáról és a privatizációs folyamatot serkentő kormányzati eszközrendszerről. Ezt követően a szerzők elemzik a privatizációs folyamat hatékonyságra, minőségre, eredményességre, a közoktatási szelekció mértékére, valamint a roma tanulók szegregációjára gyakorolt hatását. A tanulmány a feltárt problémák megoldásával kapcsolatos néhány oktatáspolitikai dilemma felvázolásával zárul.
\end{abstract}

